\title{
Smallholder grain postharvest management in a variable climate: Practices and perceptions of smallholder farmers and their service-providers in semi-arid areas
}

Tinashe Nyabako', Brighton M. Mvumi ${ }^{1 *}$, Tanya Stathers² and Honest Machekano ${ }^{3}$

${ }^{1}$ Department of Soil Science \& Agricultural Engineering, Faculty of Agriculture, University of Zimbabwe, Box MP 167 Harare, Zimbabwe tnyabako@gmail.com ;

${ }_{2}^{2}$ Natural Resources Institute,University of Greenwich, Central Avenue, Chatham Maritime, Kent ME4 4TB, UK, t.e.stathers@greenwich.ac.uk ;

${ }^{3}$ Department of Crop Science, Faculty of Agriculture, University of Zimbabwe, Box MP 167 Harare, Zimbabwe, hmachekano0@gmail.com

†Author's current address: Department of Biological Sciences and Biotechnology. Botswana International University of Science and Technology, P. Bag 16, Palapye, Botswana.

*Author for correspondence: mvumibm@agric.uz.ac.zw; mvumibm@hotmail.com 
Smallholder grain postharvest management in a variable climate: Practices and perceptions of smallholder farmers and their service-providers in semi-arid areas

\section{Abstract}

Field data on current crop postharvest management practices and perceptions from smallholder farming communities in an increasingly variable climate are scarce. Our study used a multidimensional approach to explore the practices and perceptions of these communities and their service-providers regarding grain postharvest management in semi-arid Mbire and Hwedza districts in Zimbabwe. A total of 601 individual household interviews, six focus group discussions with women and men, and interviews with 40 district stakeholders and 53 community key informants were conducted. Farmers and service-providers explained how climate change was threatening food security; causing reduced and more variable maize and sorghum yields of below $0.5 \mathrm{t} / \mathrm{ha}$, alongside higher grain storage insect pest pressure. Increased food insecurity and concerns regarding grain theft have driven a shift from bulk storage in traditional outdoor free-standing granaries to polypropylene bags stacked inside the living quarters. Poor and improper use of grain protectants in these circumstances exacerbate the health-related risks. Agricultural extension officers were the most common source of agronomic and postharvest information followed by farmer-to-farmer information exchange. Targeted postharvest training; participatory field trials involving agricultural extension staff, farmers and other service-providers; and policy dialogue around grain postharvest management and food security are proposed to help in strengthening the capacity to reduce grain postharvest losses under increasingly unpredictable conditions.

Key words: storage pest management, smallholder grain storage, climate change impacts, postharvest management policy dialogue

\section{Introduction}

Southern Africa has been experiencing fluctuating annual rainfall patterns and increasing temperatures (Brown et al. 2012; IPCC 2014). There is a clear shift in the prevailing climate with an increased frequency of drought and occurrence of extreme weather events which pose a significant risk to the existing food, biological and livelihood systems (Thornton et al. 2014), associated national policies and human health (Mubaya et al. 2012). The changes in temperature and rainfall patterns in some sub-Saharan Africa (SSA) countries such as Zimbabwe suggest that a new classification of agro-ecological regions may be required to correspond to the current climatic patterns (Mugandani et al. 2012; Nyabako and Manzungu 2012). In Zimbabwe, agro-ecological 
regions I and II (see details in Mugandani et al. (2012)) are primarily high-potential, specialised or intensive mixed farming system areas, while agro-ecological region III has semi-intensive farming systems. Regions IV and V are primarily dry, characterized by low, inconsistent rainfall ( $<600 \mathrm{~mm})$ and high temperatures with extensive farming systems. There is a growing realization that temperature, increased ultra-violet radiation and lower relative humidity levels will affect pest distribution and other characteristics leading to greater field and postharvest pest problems (Sharma and Prabhakar 2014). Direct impacts of climate change on postharvest factors are barely reported in the literature (Karuppaiah and Sujayanad 2012; Moses et al. 2015; T. Stathers et al. 2013), highlighting the need to investigate the perceptions, knowledge and practices of smallholder farmers and their service-providers living in the most-affected semi-arid areas of developing countries.

Insect pests are poikilothermic ectotherms and thus respond to climate-induced changes in environmental temperature. Temperature increases towards the optimum development ranges $\left(\mathrm{T}_{\mathrm{opt}}\right)$ intensifies insect pest activity, e.g. flight, mating, feeding and growth rate and consequently shorten generation time and increased reproductive rates (Neven 2000; Willmer et al. 2005). Thus, the current warming trends in southern Africa (IPCC 2014) are likely to increase postharvest pest activity, abundance and distribution with negative effects on the efficacy of current pest control measures (Sharma 2014; T. Stathers et al. 2013). There has been limited field work on how abiotic climatic factors affect stored grain systems (Moses et al. 2015) and how smallholder farmers perceive and respond to effects of climate change on their stored-food reserves (T. Stathers et al. 2013). The insufficient understanding of climate change impacts on smallholder agri-food systems led the Zimbabwean Government to draft the Zimbabwe National Climate Response Strategy (Ministry of Environment and Natural Resources Management 2013) to leverage greater efforts towards reducing climate change-related risks. The relationships between climate change and postharvest crop losses are not yet well-understood at any level (T. Stathers et al. 2013).

Existing postharvest losses of maize across SSA are already significant. The African Postharvest Losses Information System (APHLIS) estimates suggest an annual loss of $19 \%$ of the maize produced in Zimbabwe during the period 2009 to 2018, and 12-13\% for sorghum ( Rembold et al. 2011; APHLIS 2019). These losses occur at different stages along the postharvest chain, starting from harvesting to consumption (see details in Tefara (2012)). Losses during the storage phase are known to be more important, with insect pests being a key causal factor. Whilst a range of different insect pests attack stored maize, the larger grain borer (LGB), Prostephanus truncatus Horn. is of special interest as it has only recently occurred and rapidly spread in Zimbabwe and neighboring countries (Nyagwaya, Mvumi \& Saunyama, 2010; Rembold et al., 2011; Muatinte et al., 2019). 
Prostephanus truncatus destroys a high fraction of the grains it attacks compared to other pests such as Sitophilus spp. which attack many grains but destroy relatively few. While the threat to food security has increased due to the greater climate and related postharvest challenges previously mentioned, the lack of clear and specific policies that speak to the specific associated threats is a cause for concern.

The current study was conducted to: (i) determine the existing postharvest management (PHM) practices and perceptions of smallholder farmers and their service-providers in the context of changing climates; (ii) explore the effects of climate change and variability on smallholder farmer postharvest management practices in two climatically contrasting (rainfall, temperature, and farming system) agro-ecological zones of semi-arid Zimbabwe; and (iii) identify possible policy interventions that may increase food and nutrition security from a postharvest management perspective.

\section{Methods}

\subsection{Study area}

Hwedza and Mbire districts in Zimbabwe were purposively selected to provide not only contrasting agro-ecological zones, but also to explore the influence of their diverse biophysical and socioeconomic circumstances, with both being perceived as vulnerable to climate-related risks. Hwedza district lies in the Save Valley basin and is pre-dominantly in agro-ecological region II and III, characterised by annual rainfall of 750 - $1000 \mathrm{~mm}$ per annum and a mean annual temperature range of 18-30 ${ }^{\circ} \mathrm{C}$ (Mugandani et al. 2012; Vincent et al. 1960). The smallholder farmers in this area practice rain-fed farming (Mugandani et al. 2012). Signs of climate change have already been experienced in Hwedza district through higher temperatures and increased frequency of mid-season droughts (Mapfumo et al. 2010; Rurinda et al. 2015). Mbire district is mainly in agro-ecological region IV and is characterised by low annual rainfall below $450 \mathrm{~mm}$ and generally high temperatures of between 28-42 ${ }^{\circ} \mathrm{C}$ (Mugandani et al. 2012; Vincent et al. 1960). 


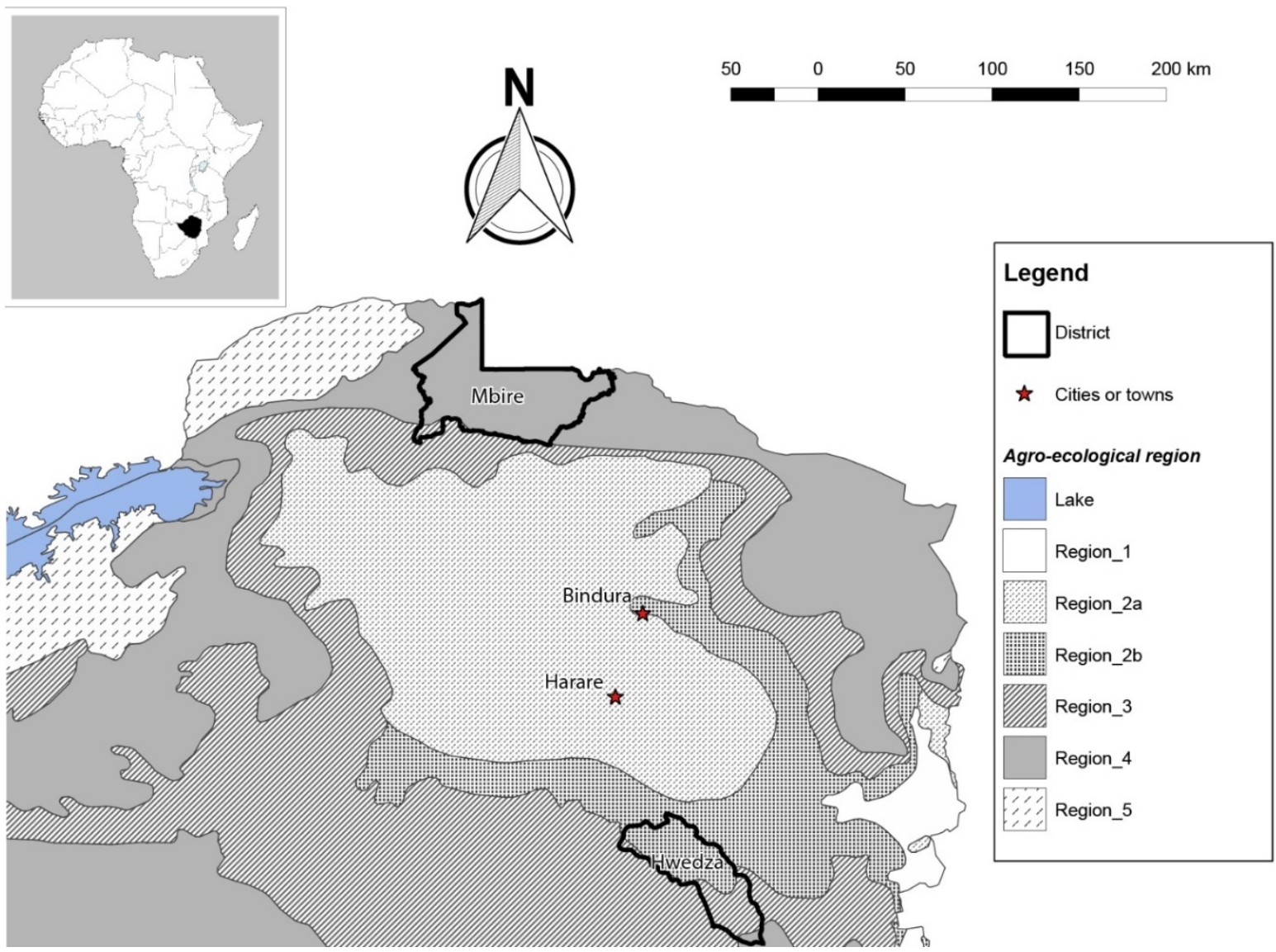

Fig. 1 Part of map of Zimbabwe showing the study areas

Mbire district is a sedimentary region located within the sandy plateau of the Zambezi Valley basin, rendering it prone to flooding and erosion (Dube et al. 2014), compared to the granite-derived sandy and clay soils with a belt of para-ferralitic soils in Hwedza (Nyamapfene 1985; Wuta and Nyamugafata 2012). Much of Mbire’s agriculture is flood-based along river and stream banks (Dube et al. 2014), and the vegetation largely consists of drought-resistant trees and bushes. However, Hwedza has savanna woodland with Brachystegia spp as the dominant tree and Hyperennia spp. as the dominant grass species (Gadzirayi et al. 2007; Macdonald 2003). These conditions may predispose stored maize grain to damage from $P$. truncatus which is known to thrive in naturally wooded areas (Dunstan and Magazini 1980; Harnish and Krall 1984; B. Muatinte et al. 2019; Nang'ayo et al. 2002).

\subsection{Target population, sample size, sampling techniques and data collection methods}

The study was conducted between December 2013 and March 2014 during the postharvest season in Hwedza and Mbire districts. Three wards (a ward is an administrative geographical area lying at a level between a village and a district) were selected (Table 1) using a purposive sampling technique in each district in consultation with district stakeholders to include locations where farmers were actively producing crops and livestock. 
122 Table 1 Number of community key informants and key secondary stakeholders interviewed in Hwedza and Mbire districts

\begin{tabular}{|c|c|c|c|c|}
\hline District & Ward & $\begin{array}{l}\text { Coordinates } \\
\text { (Lat, Long) }\end{array}$ & $\begin{array}{l}\text { *Key Secondary } \\
\text { Stakeholders }\end{array}$ & $\begin{array}{l}\text { Community Key } \\
\text { Informants }\end{array}$ \\
\hline \multirow[t]{3}{*}{ Hwedza } & Makwarimba & $31.6452-18.6486$ & & 7 \\
\hline & Ushe & $31.8667-18.7995$ & 18 & 7 \\
\hline & Goneso & $31.8795-18.8885$ & & 8 \\
\hline \multicolumn{2}{|c|}{ Subtotal } & & 18 & 22 \\
\hline \multirow[t]{3}{*}{ Mbire } & Chirunya & $30.5877-16.3146$ & & 10 \\
\hline & Chitsungo & $30.4714-16.2986$ & 22 & 11 \\
\hline & Mahuwe & $30.7434-16.3788$ & & 10 \\
\hline \multicolumn{2}{|c|}{ Subtotal } & & 22 & 31 \\
\hline \multicolumn{2}{|c|}{ Grand Total } & & 40 & 53 \\
\hline
\end{tabular}

*Key secondary stakeholders were not selected at ward level but only at district level from prominent agribusiness enterprises and technical stakeholders or service-providers within the district

STATA 12 was used to randomly pick 10 villages from each of the selected wards. Sampling frames consisting of lists of all households in the selected wards were obtained from local staff of the Department of Agricultural Technical and Extension Services (AGRITEX), in the Ministry of Agriculture, Mechanisation and Irrigation Development. Ten households were randomly picked from each of the selected villages. In total, 100 households were sampled per ward to give coverage of approximately $10 \%$ of the existing number of households within each ward. In Hwedza district, a total of 300 households were interviewed while 301 were interviewed in Mbire giving a total of 601 respondent households for the two districts. To cater for cases where the originally selected household was child-headed, the household head (HHH) was absent or deceased, a 40\% reserve of the randomly selected ten households per village constituted a pool for replacement.

To triangulate and complement the household level data, qualitative data were collected from the district stakeholders and the community. At least ten qualitative stakeholder interviews were conducted at each district level, while at least seven key informant interviews were conducted in each of the three wards in each district giving a total of 22 and 31 community key informants in Hwedza and Mbire Districts respectively (Table 1). In both districts, focus group discussions (FGDs) were conducted with groups comprising of 15-20 women and 15-20 men of varying age groups and resource-endowments. Community leaders including village heads, headmen, councillors and traditional healers also participated in the FGDs. A total of 40 stakeholders were interviewed using a qualitative checklist tool. The stakeholders were selected on the basis of (i) area of specialization, (ii) working experience in the district, and (iii) link to farming activities, the 
environment and climate-related issues. They included Government of Zimbabwe departments, Non-Governmental Organisations, parastatals, farmers’ unions and agro-dealers.

Tools used in the community profiling of climatic hazards and risks for the FGDs (FGDs), individual stakeholders and local or community key informants and individual household interviews were jointly developed by a trans-disciplinary team from the Food and Agricultural Organization of the United Nations, University of Pretoria, Natural Resources Institute of the University of Greenwich, Soil Fertility Consortium of Southern Africa (SOFECSA) and the University of Zimbabwe. Following pre-testing and adjustments, household data were collected using a structured and coded questionnaire with a few open-ended questions that were post-coded. Tools for qualitative data collection were similarly pre-tested and adjusted accordingly prior to administration. All the tools were administered manually through face-to-face interviews.

\subsection{Data management and analysis}

The household questionnaire data were entered into CSPRO 6.1 software before being exported to IBM SPSS 16 software for statistical analysis. Analysis included cross-tabulations, calculation of frequencies, correlations and Chi-square tests of associations (Arkkelin 2014; Kpolovie 2017). The qualitative data collected were largely nominal in nature, with the scales of measurement used for farmers' knowledge, and perspectives being ordinal, while quantitative data were recorded for farmers’ resource endowments. Qualitative data from FGDs, key informant interviews and district stakeholders were processed by a multi-disciplinary team of researchers who summarised similar responses from different respondents and categorised the responses into thematic areas. In addition to providing a broader picture of issues and trends in the study communities and districts targeted, the qualitative data were used to explain some of the observations from the quantitative analysis of household level data. 


\section{Results}

\subsection{Household characteristics}

177 There were over 10\% more female-headed households amongst the respondents in Hwedza than Mbire district (Table 2). The typical age range of the HHH across the two districts was 40-60 years, while over $18 \%$ of the HHHs were older than 70 years. More than $60 \%$ of households were in monogamous marriages, with twice as many (29.7\% vs $12.6 \%)$ widowed respondents in Hwedza than Mbire respectively, and more polygamous marriages in Mbire than Hwedza (Table 2). Literacy was high in both districts with $>88 \%$ of HHHs being able to read and write. Only 12 and $6.7 \%$ of HHHs interviewed in Mbire and Hwedza respectively, had not acquired any formal education. Almost $18 \%$ of the HHHs interviewed in Hwedza were functionally disabled with limited participation in physical activities around the household.

The main cereal crop grown in Hwedza was maize (98\%) while in Mbire both maize (77\%) and sorghum (18\%) were grown as main crops (Table 2). In Mbire, farmers also grew a lot of their crops in fields along the river banks. Respondents in Mbire indicated a strong preference for maize as opposed to to sorghum, regardless of its frequent failure under dryland production due to the low rainfall experienced in the area.

Income was mainly derived from cropping practices and livestock to varying degrees in both Hwedza and Mbire (Table 2). Where respondents' main livelihood/ income source had changed in the last 10 to 20 years, there had been a perceived decrease in income for $47 \%$ and $68 \%$ of responding households in Hwedza and Mbire respectively. In contrast, few respondents perceived an increase in household incomes (23\% and $7 \%$ in Hwedza and Mbire respectively), or no change for 23\% (Hwedza) and $21 \%$ (Mbire). The main reason given for the observed change in livelihood source was changes in markets and sales (16\% and 49\% in Hwedza and Mbire respectively), followed by climate issues (14\% in both Hwedza and Mbire) (Fig 2). 
Table 2 Sex, education and crop choice statistics of household heads (HHH) interviewed in Mbire and Hwedza districts, Zimbabwe

\begin{tabular}{|c|c|c|c|}
\hline \multirow[t]{2}{*}{$\begin{array}{c}\text { Socio-economic } \\
\text { characteristic of } \mathrm{HHH}^{*}\end{array}$} & \multirow[t]{2}{*}{ Response } & \multicolumn{2}{|c|}{ Proportion of respondents (\%) } \\
\hline & & $\begin{array}{l}\text { Hwedza } \\
(\mathrm{N}=300)\end{array}$ & $\begin{array}{r}\text { Mbire } \\
(\mathrm{N}=301)\end{array}$ \\
\hline Sex & male & 69.3 & 82.1 \\
\hline \multirow[t]{2}{*}{ Age (years) } & $<40$ & 23 & 38.3 \\
\hline & $>70$ & 17.7 & 9.7 \\
\hline \multirow[t]{6}{*}{ Marital status } & Married/ single spouse & 64.3 & 73.8 \\
\hline & Married/ polygamous & 1.7 & 10.3 \\
\hline & Widowed & 29.7 & 12.6 \\
\hline & Separated/ divorced & 3.7 & 2.7 \\
\hline & Cohabiting & 0.0 & 0.0 \\
\hline & Single/ never married & 0.7 & 0.7 \\
\hline Ability to read or write & yes & 89.3 & 87.7 \\
\hline Functionally disabled? & yes & 17.7 & 9.3 \\
\hline \multirow[t]{6}{*}{ Education level } & None & 6.7 & 12.0 \\
\hline & Primary & 43.3 & 38.9 \\
\hline & Secondary & 47.3 & 47.5 \\
\hline & Tertiary & 2.0 & 1.7 \\
\hline & Vocational & 0.3 & 0.0 \\
\hline & Other & 0.3 & 0.0 \\
\hline \multirow[t]{4}{*}{ Main crops grown } & Maize & 98 & 77 \\
\hline & Sorghum & 0 & 18 \\
\hline & Millets, Wheat, Cassava & 0 & 0 \\
\hline & Other & 0 & 1 \\
\hline \multirow[t]{6}{*}{ Main income sources } & Sale of cereals and pulses & 19.8 & 4.7 \\
\hline & $\begin{array}{l}\text { Sales of own } \\
\text { vegetables/fruits }\end{array}$ & 19.1 & 7.0 \\
\hline & Sale of cash crops & 5.2 & 36.9 \\
\hline & Sale of livestock & 4.1 & 17.9 \\
\hline & $\begin{array}{l}\text { Irregular daily labour, casual } \\
\text { worker }\end{array}$ & 12.4 & 12.0 \\
\hline & Remittances & 14.8 & 2.6 \\
\hline
\end{tabular}


207

208

209

210

211

212

213

214

215

216

217

218

219

220

221

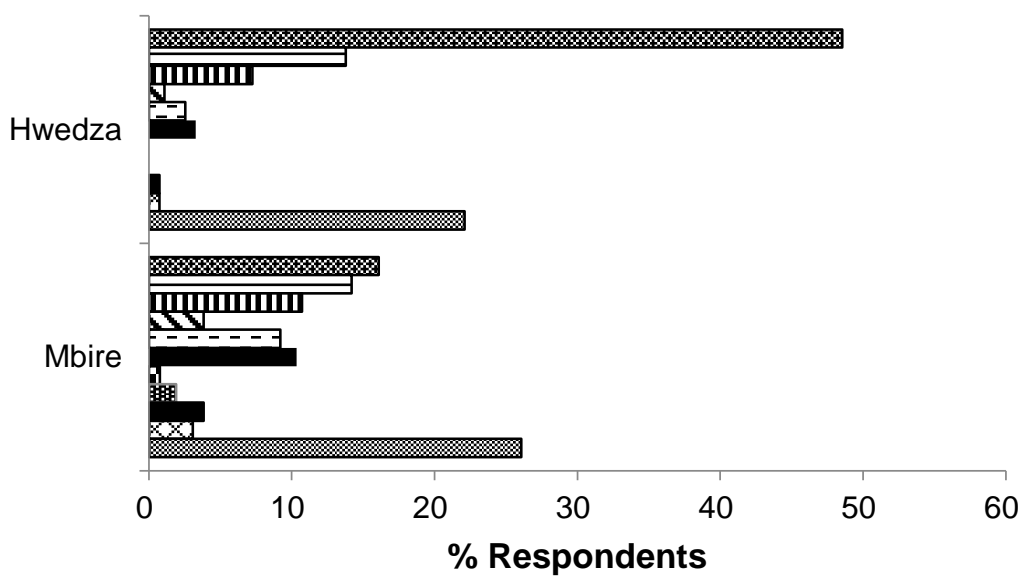

* Market/Sales Changes

$\boxminus$ Climate issues

mMoney/Cash Issues

- Capital issues

๘Production change

- Labour

QTrading

B Deaths

- Responsibilities

cothers

No answer

Fig. 2 Reasons for change in main livelihood / income source during the last 10-20 years as perceived by smallholder farmers in Mbire and Hwedza districts, Zimbabwe

\subsection{Current postharvest practices}

\subsubsection{Source of seed}

At the time of this study, there was a high usage of self-produced maize planting seed amongst farmers in both Hwedza and Mbire districts with more than $50 \%$ of maize seed being self-retained. Most farmers in Hwedza (95\%) planted the higher yielding commercial maize hybrids while in Mbire, use of hybrids, was relatively low (37\%), with most farmers planting either landraces (47\%) or retained seeds including hybrids (40\%). The hybrid maize seed included both certified commercial seed readily available at local or town shops as well as subsidised seed provided under Government of Zimbabwe support programmes (Fig 3).

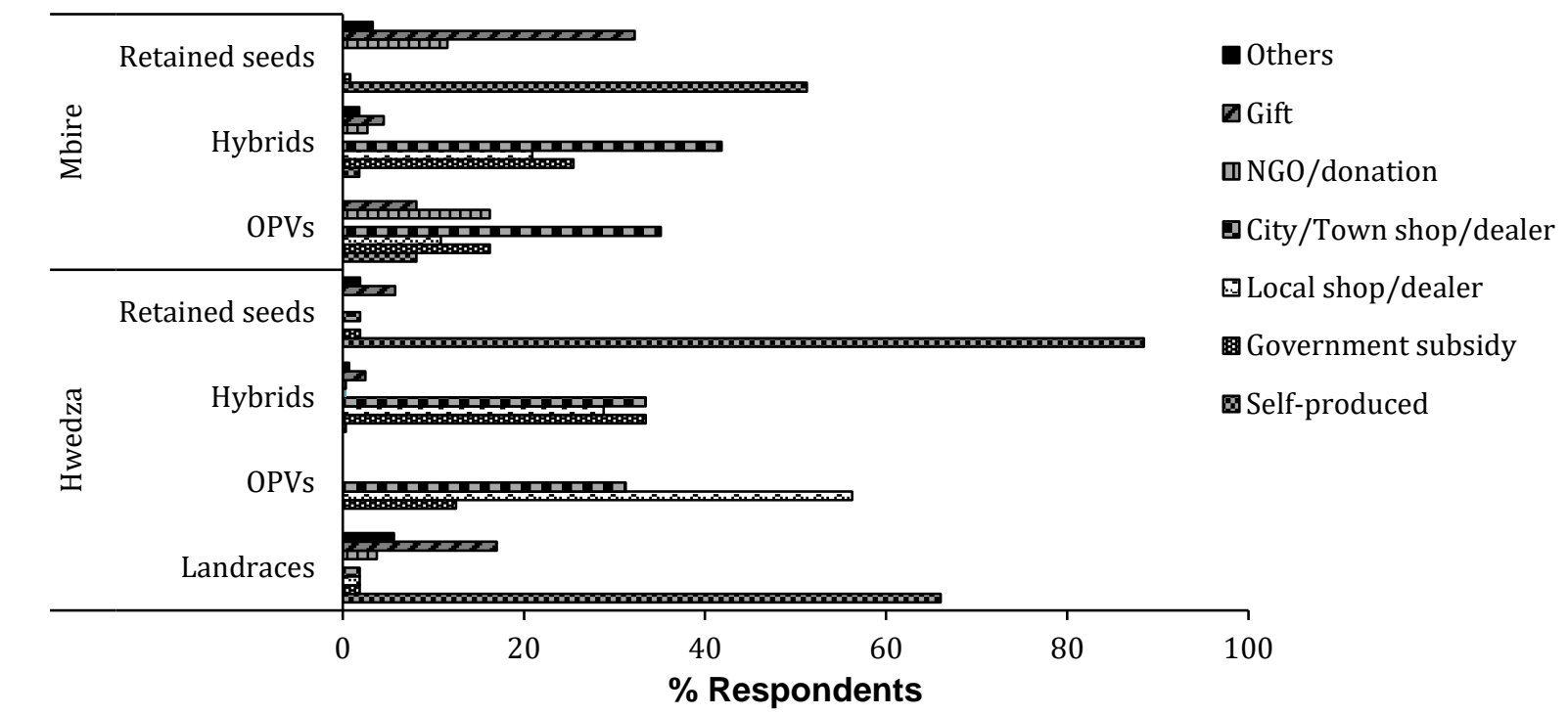

Fig. 3 Sources of planted maize seed in 2011/12 season in Mbire and Hwedza districts, Zimbabwe (OPVs = open pollinated varieties) 
226 For farmers who planted maize in the 2011/2012 season, 83\% and 60\% used self-retained seed in

227

228

229

230

231

232

233

234

235

236

237

238

239

240

241

242

243

244

245

246

247

248

249

250

251

252

253

Hwedza and Mbire, respectively. Stakeholders interviewed reported the wide fluctuations in rainfall patterns and extended dry spells as contributing to agricultural problems currently being faced by their communities. High incidences of poor seed germination were reported by stakeholders and farmers, and were linked to inadequate rainfall, unpredictable rainfall patterns and extended dry spells to which farmers responded by retaining extra seed for re-planting. The few farmers in Mbire who manage to grow maize achieve similar production levels to Hwedza farmers because the Mbire farmers cultivate the crop along the river banks which have rich sedimentary soils.

\subsubsection{Pre-storage moisture content determination}

The grain moisture content prior to storage was mainly assessed by visually inspecting it for colour, texture and physical damage, with 54\% of maize respondents doing this while only $18 \%$ of the sorghum grain respondents did it. Other methods included the length of time the grain was left drying in the sun (18\%) and the hardness of grain when it was bitten (11\%), although this was less commonly used for traditional grains $(<4 \%)$. Over half of the farmers who reported that they faced postharvest challenges after harvest (Mbire 84\%, Hwedza 59\%), reported using visual methods to check grain moisture content.

\subsubsection{Grain storage packaging}

Most farmers (82\% in Hwedza and 87\% in Mbire), used polypropylene bags as the main packaging containers for storage of maize grain (Fig 4). Sorghum grain was also stored packaged in polypropylene bags (77\% in Hwedza and $87 \%$ in Mbire). Over 10\% of farmers reported not using any packaging at all in both districts, i.e. they stored bulk grain. There was however, a significant correlation between the protectant treatment applied and the packaging used $(P=0.009)$. Key informant interviews and FGDs in both districts, reported the need for greater emphasis on grain storage and improved food preservation techniques given that the yields of major cereals were continuously decreasing due to climate change. 


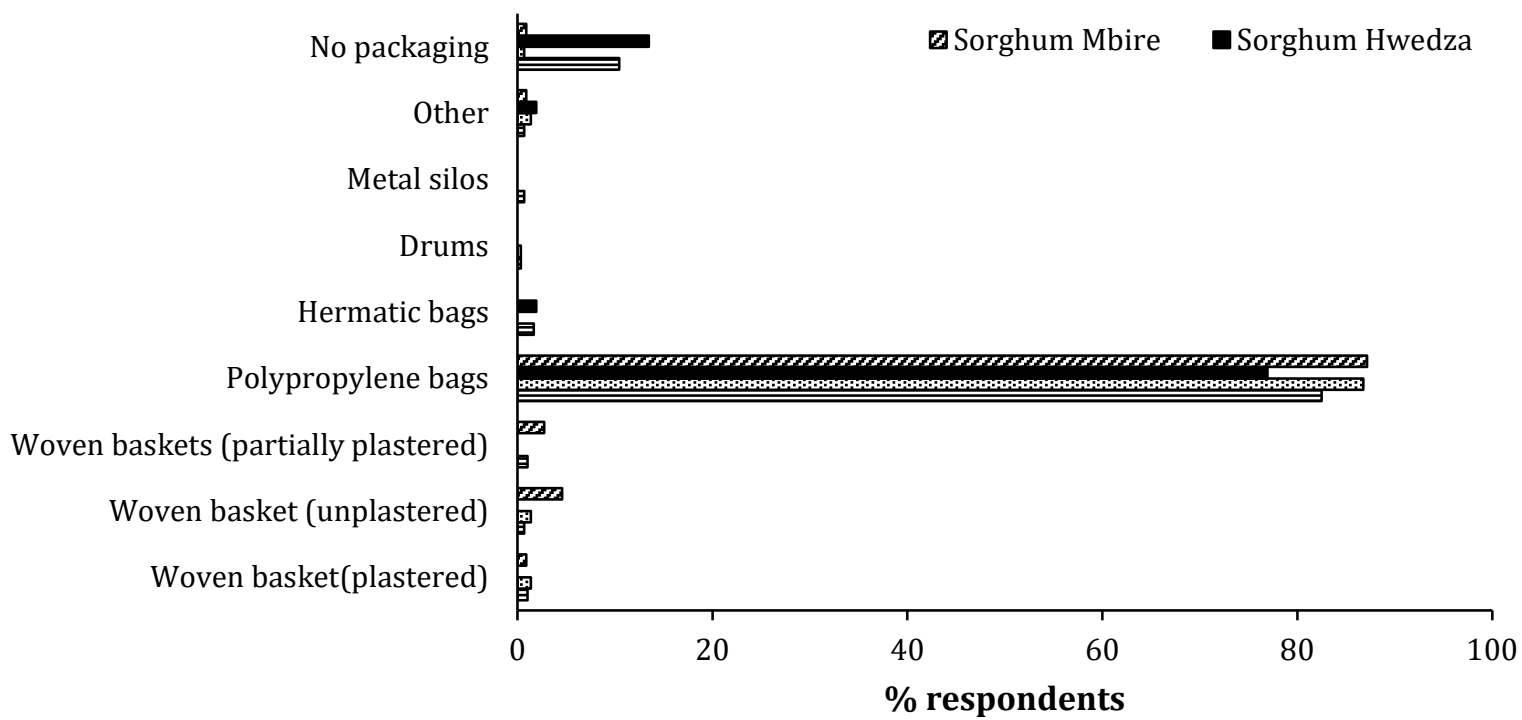

254

Fig. 4 Type of packaging used for stored maize and sorghum

\subsubsection{Grain storage facilities}

258 The majority of households (80\% and 91\% in Hwedza and Mbire respectively), used ordinary rooms inside their living quarters for storing their maize grain as opposed to solid stand-alone outdoor granaries or other options (Fig 5). FGD discussions and anecdotal data suggested that security of the grain was the main concern in shifting place of storage.

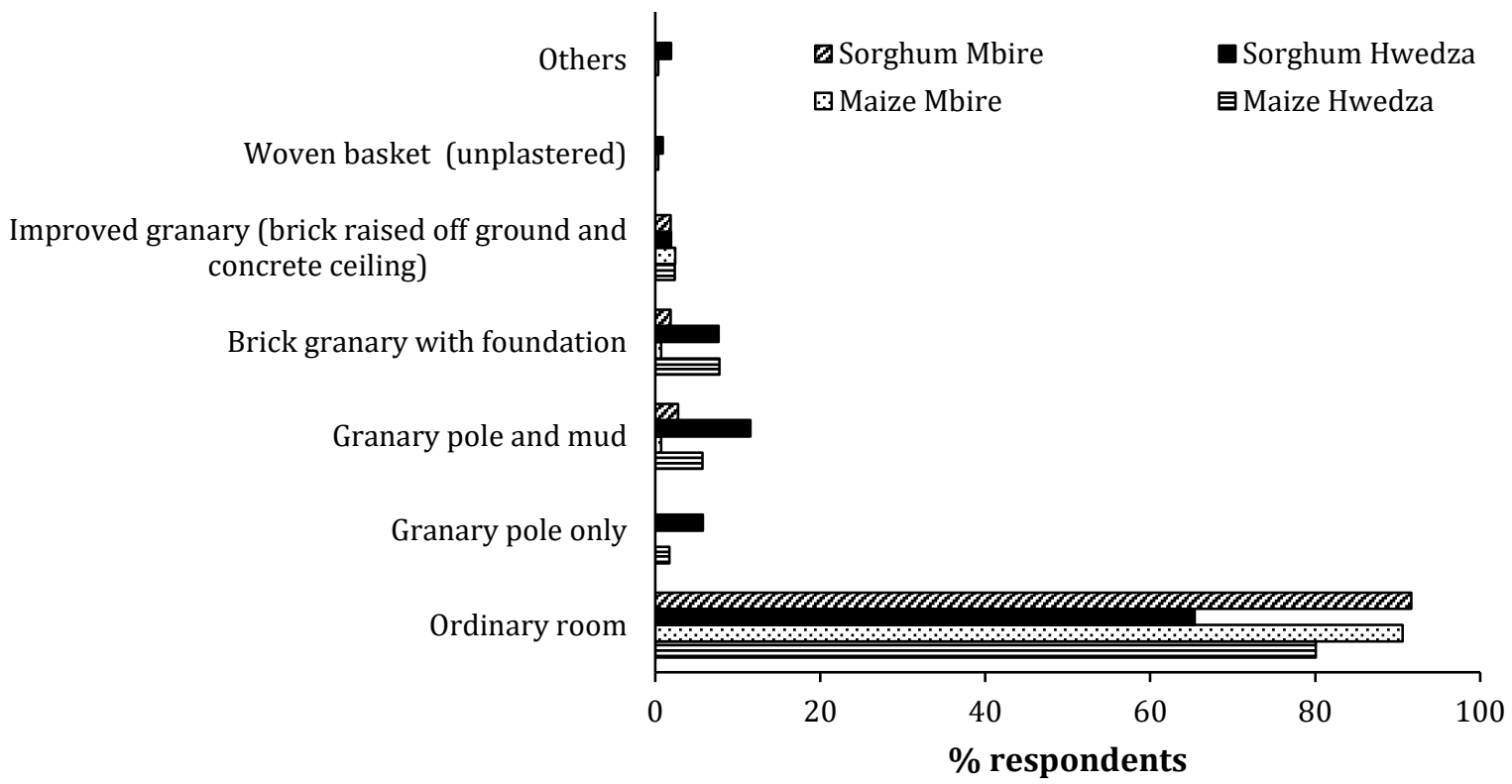

264 Fig. 5 Storage facilities used for storing maize and sorghum grain by smallholder farmers in Mbire and Hwedza districts, Zimbabwe 
Only $8 \%$ of Hwedza farmers were using brick granaries with a foundation, and only $6 \%$ used pole and mud granaries. For sorghum storage, ordinary rooms were the most commonly used storage structure in both Hwedza (65\%) and Mbire (92\%), with externally-located purpose-built structures being less prevalent especially in Hwedza, i.e. pole and mud granaries (17\%), improved granaries (17\%), and brick granaries with a foundation (17\%).

\subsubsection{Stored grain protection}

The use of commercially-available chemical grain storage protectants was high amongst respondents, 88\% of farmers in Hwedza, and 81\% of farmers in Mbire. Traditional treatments (e.g. gum tree leaves, ash, plant extracts) were still used by some households mainly in Mbire (12\%). In both districts, only $7-8 \%$ of households did not use any storage protection treatments at all. Compared to 10 to 20 years ago, the use of plant extracts as a maize grain protectant has declined by two-thirds from $11 \%$ to $4 \%$ in both Hwedza and Mbire, while the use of chemical grain protectants has increased from 77\% to 82\% in Hwedza, and from 52\% to 71\% in Mbire (Table 3).

Table 3 Changes in grain protectant use on maize and sorghum in Mbire and Hwedza districts compared to 10-20 years ago as perceived by smallholder farmers

\begin{tabular}{|c|c|c|c|c|c|c|c|}
\hline \multirow[t]{2}{*}{ District } & \multirow{2}{*}{ Grain type } & \multirow{2}{*}{ Period } & \multicolumn{5}{|c|}{ Grain protectant used } \\
\hline & & & None & Ash & $\begin{array}{r}\text { Commercial grain } \\
\text { storage pesticide }\end{array}$ & $\begin{array}{r}\text { Plant } \\
\text { extracts }\end{array}$ & Others \\
\hline \multirow{4}{*}{$\begin{array}{l}\text { Hwedza } \\
(\mathrm{N}=300)\end{array}$} & Maize & 10-20 years ago (\%) & $9.1_{\mathrm{a}}$ & $3.0_{a}$ & $76.8_{a}$ & $10.7 \mathrm{a}$ & $0.3_{\mathrm{a}}$ \\
\hline & & Current (2013) (\%) & $12.0_{\mathrm{a}}$ & $2.0 \mathrm{a}$ & $81.7 \mathrm{a}$ & $4.0_{\mathrm{a}}$ & $0.3 \mathrm{a}$ \\
\hline & Sorghum & $10-20$ years ago (\%) & 94.9 a & 0 & $4.4_{a}$ & $0.7 \mathrm{a}$ & 0 \\
\hline & & Current (2013) (\%) & $94.9 \mathrm{a}$ & 0 & $4.7 \mathrm{a}$ & $0.3 \mathrm{a}$ & 0 \\
\hline \multirow{4}{*}{$\begin{array}{l}\text { Mbire } \\
(\mathrm{N}=301)\end{array}$} & Maize & $10-20$ years ago (\%) & $16.3_{b}$ & $19.9_{b}$ & $51.8_{b}$ & $11.3 \mathrm{a}$ & $0.7 \mathrm{a}$ \\
\hline & & Current (2013) (\%) & $15.0_{\mathrm{b}}$ & $9.6 \mathrm{~b}$ & $71.4 \mathrm{~b}$ & $3.7 \mathrm{a}$ & $0.3 \mathrm{a}$ \\
\hline & Sorghum & 10-20 years ago (\%) & $66.8 \mathrm{~b}$ & $5.3 \mathrm{a}$ & $21.9 \mathrm{a}$ & $5.0_{\mathrm{b}}$ & $1.0_{\mathrm{a}}$ \\
\hline & & Current (2013) (\%) & $64.8_{\mathrm{b}}$ & $3.0_{a}$ & $29.9_{\mathrm{b}}$ & $2.0_{a}$ & $0.3_{\mathrm{a}}-\mathrm{c}$ \\
\hline
\end{tabular}

Note: Values for the same crop row (i.e. including rows denoting current and 10-20 years ago) not sharing the same subscript are significantly different at $p<0.05$ in the two-sided test of equality for column proportions. Cells with no subscript were not included in the test. Tests assume equal variances.

Over 94\% of farmers in Hwedza and 65\% of farmers in Mbire were not using any storage protectant on their sorghum grain, and there has been no significant change since 10 to 20 years ago. There has, however, been significant increase in the use of commercial pesticides and significant decrease in plant extract use for traditional grains (Table 3). In Hwedza, 61\% of farmers indicated there had 
292

293

294

295

296

297

298

299

300

301

302

303

304

305

306

307

308

309

310

311

312

313

314

been no change in the quantity of chemical protectants used, while 31\% reported having increased their dosage, and 7\% claimed to have decreased their dosage. In Mbire district, 78\% indicated no change in dosage used, and 15\% indicated an increase in the amount of protectant used, and $7 \%$ claimed to have decreased their dosage.

Among those reporting an increase in the pesticide dosage used when storing maize now compared with 10-20 years ago (>30\%) or for sorghum (>50\%), an increase in pests and insecticide tolerance were the dominant explanations given (Fig 6). Over 93\% of farmers did not provide a response to the question on the reason for change in chemical protectant use in sorghum. The level of knowledge about storage pests was reported to have increased mainly in Mbire (17\%) resulting in general increases in chemical protectant use especially on maize grain (52 to $71 \%$ of respondents).

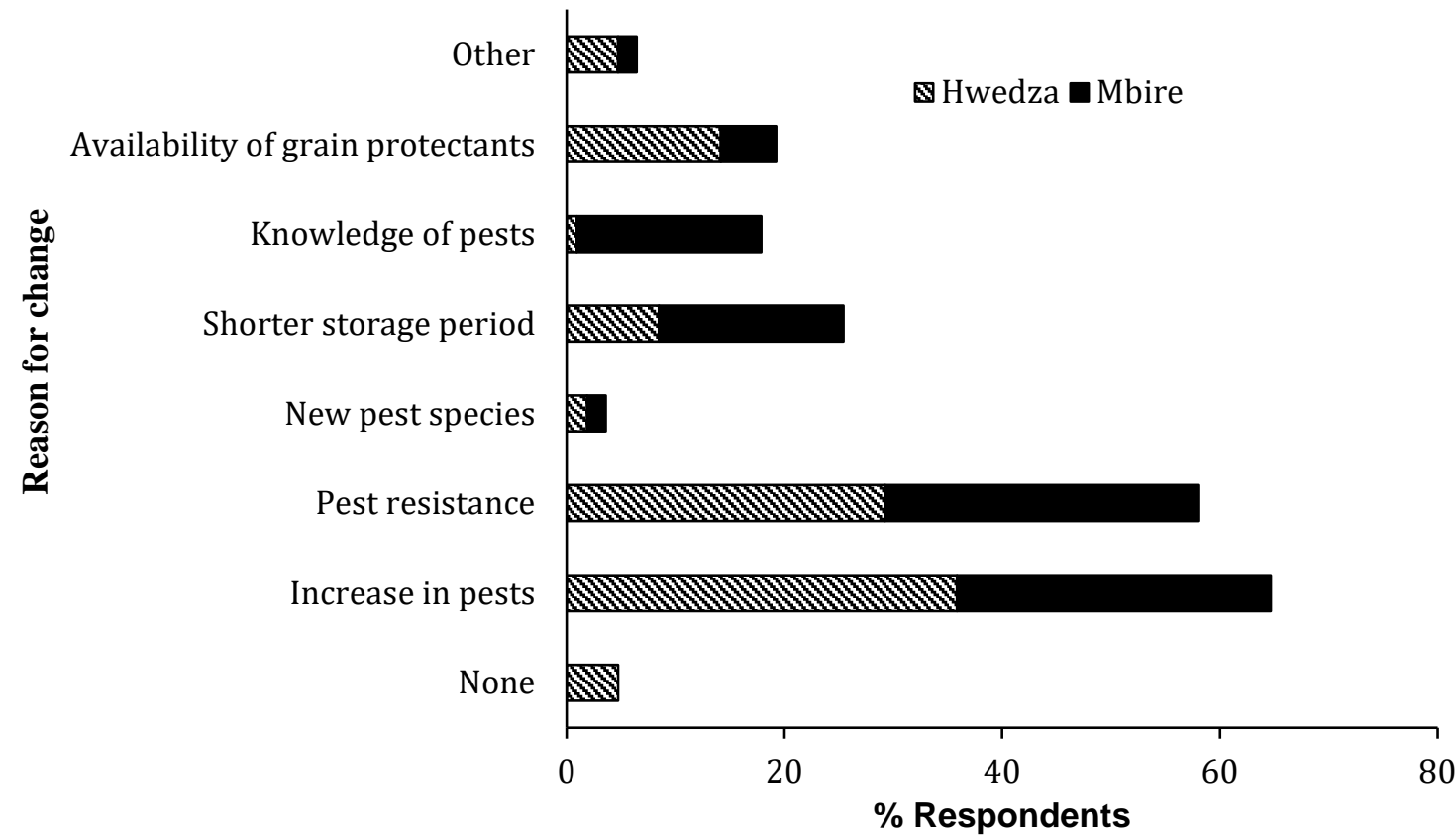

Fig. 6 Reasons for change in chemical grain protectant use for maize as perceived by smallholder farmers in Mbire and Hwedza districts, Zimbabwe

Stakeholder interviews revealed that although farmers in both districts have increasingly adopted the use of commercial synthetic grain protectants, in Mbire these grain protectants were now also being applied on traditional grains (mainly sorghum) and pulses (mainly cowpeas). This increased adoption of synthetic commercial grain protectants was attributed to an increase in populations of storage pests observed in stored grain, especially weevils, Sitophilus spp. for cereals and bruchids, Callosobruchus spp. for cowpeas. Key informants and farmers reported that the shortage of maize grain supplies in Mbire was exacerbated by the lack of a national Grain Marketing Depot in the 
area. Farmers in FGDs reported that when they sell their livestock, there were no ready grain suppliers offering grain for sale at reasonable commercial prices commensurate with the livestock sale prices. Private traders were reported to bring mainly maize grain but at exorbitant prices, leaving farmers economically disadvantaged especially when bartering their livestock for maize grain.

\subsubsection{Gender roles in crop postharvest management}

Grain postharvest management activities in the two districts were mainly done by members of the family with very little use of hired labour (Fig 7). In most households, all the family members helped with the postharvest activities.

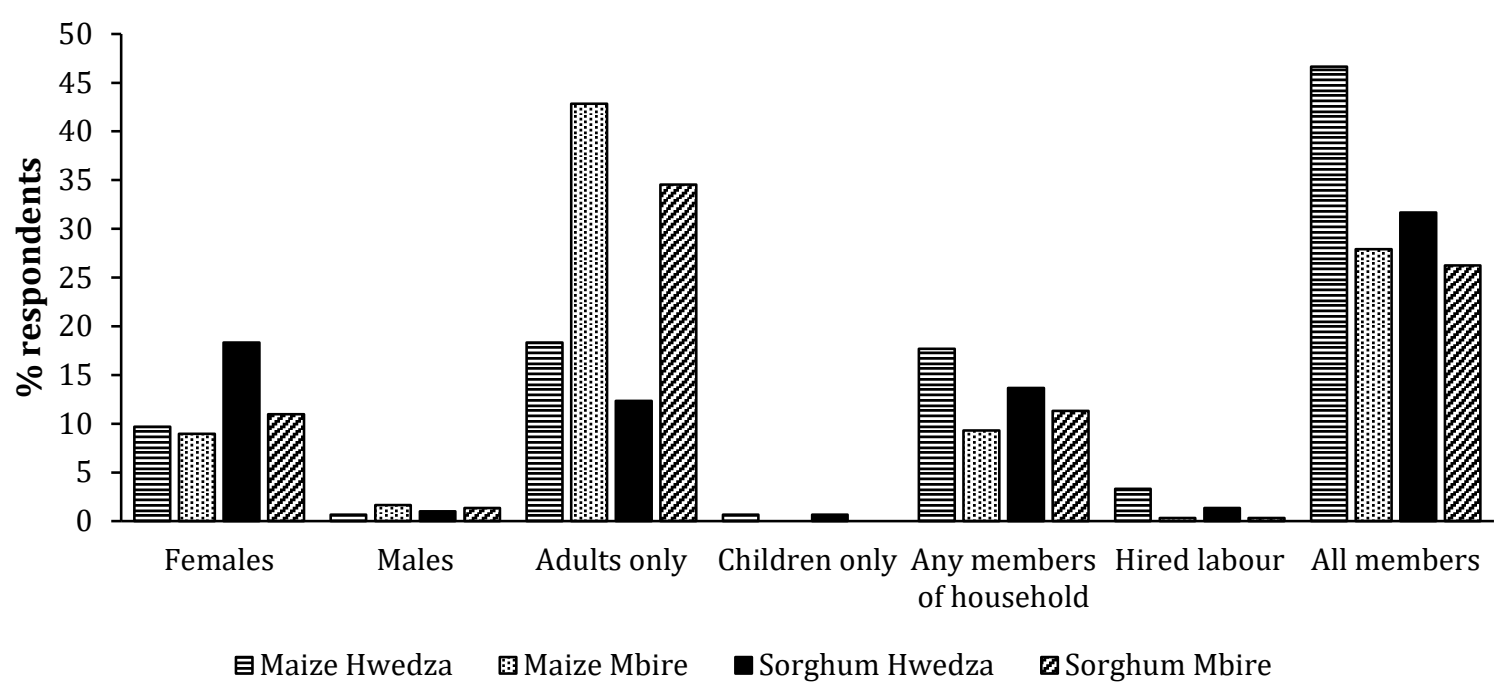

Fig. 7 Household members' involvement in the postharvest management of the maize and sorghum in Mbire and Hwedza districts, Zimbabwe

In $12-43 \%$ of responding households, only the adults did the $\mathrm{PH}$ activities, and in $10-20 \%$ of households only female members did the PH activities. There were very few households $(<3 \%)$ where only males did the $\mathrm{PH}$ activities, and even fewer $(<2 \%)$ where only children did the $\mathrm{PH}$ activities (Fig 7).

\subsection{Grain postharvest challenges and their causes}

Most respondents could not explain what caused their postharvest challenges (81\% in Mbire, 27\% in Hwedza). Attack by pests beginning in the field was cited as the leading cause of postharvest challenges in Hwedza (41\%), but less so in Mbire (10\%), while 21\% of respondents in Hwedza, reported that storage pests accounted for the losses in maize. 
341 Many Mbire farmers (38\%) indicated that they suspected new postharvest insect species had arrived 342 in their area, while in Hwedza only 3\% indicated new insect species as a potential problem. It was 343 not clear if the farmers knew which insect species caused postharvest losses. In Hwedza, 74\% of 344 farmers did not respond to the question on changes in the seasonality of insects (Table 4). Changes 345 in seasonality of the occurrence of pests were noted by $23 \%$ of respondents in Hwedza and $36 \%$ in 346 Mbire. 
Table 4 Effects of temperature and rainfall changes on pest abundance and seasonality as perceived by smallholder farmers in Mbire and Hwedza districts, Zimbabwe

\begin{tabular}{|c|c|c|c|c|c|c|c|c|c|c|c|c|}
\hline District & Question & Responses & Percei & mean temp & rature chas & ge (\%) & & Percei & ved mean & rainfall chas & ge (\%) & \\
\hline \multirow{8}{*}{$\begin{array}{l}\text { Hwedza } \\
(\mathrm{n}=300)\end{array}$} & \multirow{4}{*}{$\begin{array}{l}\text { Perceived } \\
\text { effect on } \\
\text { pest } \\
\text { abundance } \\
\text { change }\end{array}$} & & No response & Increased & Decreased & Range altered & Other & No response & Increase & Decreased & Range altered & Other \\
\hline & & - No response & 12.4 & 78.1 & 2.7 & 4.1 & 2.7 & 5.5 & 8.2 & 69.9 & 12.3 & 4.1 \\
\hline & & & 6.4 & 81.8 & 3.4 & 7.9 & 0.5 & 1.5 & 11.8 & 81.3 & 4.9 & 0.5 \\
\hline & & $\begin{array}{l}\text { - Decreased } \\
\text { pest } \\
\text { abundance }\end{array}$ & 4.1 & 83.3 & 4.2 & 4.2 & 4.2 & 0 & 12.5 & 79.2 & 8.3 & 0 \\
\hline & \multirow{4}{*}{$\begin{array}{l}\text { Perceived } \\
\text { effect on } \\
\text { pest } \\
\text { seasonality } \\
\text { change }\end{array}$} & - No response & 8.6 & 81.4 & 0.5 & 7.7 & 1.8 & 2.7 & 10.9 & 76 & 8.6 & 1.8 \\
\hline & & $\begin{array}{l}\text { - Changed } \\
\text { seasonality } \\
\text { of pests }\end{array}$ & 4.4 & 83.8 & 10.3 & 1.5 & 0 & 1.5 & 11.8 & 83.8 & 2.9 & 0 \\
\hline & & $\begin{array}{l}\text { - New pest } \\
\text { species }\end{array}$ & 11.2 & 44.4 & 22.2 & 22.2 & 0 & 0 & 0 & 100 & 0 & 0 \\
\hline & & • Other & 0 & 100 & 0 & 0 & 0 & 0 & 0 & 100 & 0 & 0 \\
\hline \multirow{7}{*}{$\begin{array}{l}\text { Mbire } \\
(\mathrm{n}=301)\end{array}$} & \multirow{4}{*}{$\begin{array}{l}\text { Perceived } \\
\text { effect on } \\
\text { pest } \\
\text { abundance } \\
\text { change }\end{array}$} & - No response & 34.6 & 46.2 & 15.4 & 3.8 & 0 & 11.5 & 0 & 57.7 & 30.8 & 0 \\
\hline & & $\begin{array}{l}\text { - Increase pest } \\
\text { abundance }\end{array}$ & 5.9 & 64.4 & 18.4 & 10.9 & 0.4 & 0.8 & 13 & 66.5 & 19.7 & 0 \\
\hline & & $\begin{array}{l}\text { - Decreased } \\
\text { pest } \\
\text { abundance }\end{array}$ & 10.8 & 50 & 32.1 & 7.1 & 0 & 10.7 & 32.1 & 42.9 & 14.3 & 0 \\
\hline & & • Other & 0 & 75 & 0 & 0 & 25 & 0 & 62.5 & 12.5 & 0 & 25 \\
\hline & \multirow{3}{*}{$\begin{array}{l}\text { Perceived } \\
\text { effect on } \\
\text { pest } \\
\text { seasonality } \\
\text { change }\end{array}$} & - No response & 19.1 & 67.6 & 11.8 & 1.5 & 0 & 5.9 & 13.2 & 60.3 & 20.6 & 0 \\
\hline & & $\begin{array}{l}\text { - Changed } \\
\text { seasonality } \\
\text { of pests }\end{array}$ & 3.7 & 68.5 & 26.9 & 0.9 & 0 & 0.9 & 16.7 & 72.2 & 10.2 & 0 \\
\hline & & $\begin{array}{l}\text { New pest } \\
\text { species }\end{array}$ & 7.8 & 51.3 & 16.5 & 23.5 & 0.9 & 2.5 & 11.3 & 55.7 & 29.6 & 0.9 \\
\hline
\end{tabular}


351

352

353

354

355

356

In Hwedza and Mbire, 58\% and 28\% of farmers respectively indicated that they noticed changes in grain damage levels through the increase in visible holes on kernels, while a few farmers reported changes to the smell, taste and appearance of grain. There were no respondents who reported noticing damage holes on traditional grains such as sorghum.

Table 5 Use of damaged grain by smallholder farmers in Mbire and Hwedza districts, Zimbabwe

\begin{tabular}{lrrrr}
\hline & \multicolumn{3}{c}{ Maize } & \multicolumn{3}{c}{ Sorghum } \\
\cline { 2 - 5 } & Hwedza (\%) & Mbire (\%) & Hwedza (\%) & Mbire (\%) \\
& $(\mathrm{n}=126)$ & $(\mathrm{n}=176)$ & $(\mathrm{n}=90)$ & $(\mathrm{n}=65)$ \\
\hline Food destroyed & 4.0 & 2.4 & - & - \\
Given to animals & 29.4 & 7.2 & 3.3 & 4.6 \\
Still consumed & 62.7 & 82.4 & 2.2 & 46.2 \\
N/A & 4.0 & 8.0 & 95.5 & 49.2 \\
\hline
\end{tabular}

357

N/A = a respondent who responds that he/she has no answer to the question

358

$(-)=$ no respondent offered this option as an answer

359

When grain was observed to be insect damaged during storage, the main action taken by respondents was to still consume the grain. In both districts, over $60 \%$ of farmers reported keeping damaged maize grain for family consumption, while $29 \%$ of respondents in Hwedza and $7 \%$ in Mbire fed the damaged maize grain to livestock, and only 4 and $2 \%$ of farmers in the respective districts reported destroying damaged grain (Table 5).

\subsection{Perceptions of climate change and postharvest-related factors}

Temperature and humidity were perceived to have an effect on postharvest pest abundance and seasonality. The stakeholders interviewed held similar views to the farmers regarding temperature increase and rainfall decrease coinciding with a relative increase in postharvest and field pests (Table 6). The frequent dry spells/droughts and problems of precipitation amounts being too low to sustain crop production coupled with increased demand for food aid, were also mentioned by district key informants as challenges (Table 6). 
Precipitation

Dry spells

Pests

Food aid
- Unpredictable rainfall (making cropping planning difficult, rain patterns changed since about 2003)

- Not sure when season will start; season commencement unpredictable

- Prolonged dry spells and confusing temperature patterns (in last $10-20$ years)

- Pest increase (in last 10 - 20 years)

- Reduced grain deliveries, increased demand for food aid
376

377

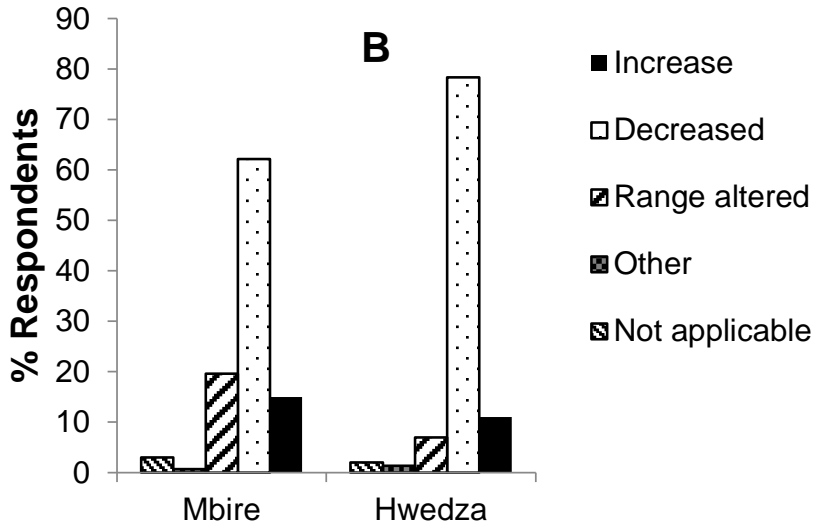

- Increased

口Decreased

aRange altered

@Other

$\square$ Not

applicable

Mbire due to low rainfall which could not sustain crop production

- Pest attack increased e.g. in 2013

- Increase in extreme hot (e.g. up to $40^{\circ} \mathrm{C}$ ), and extreme cold temperatures (in winter)

- Temperature pattern shifting, May and July used to be the coolest months; now only July is cooler (in last $10-20$ years)

- Rainfall amounts decreasing and varied or erratic

- Cropping seasons becoming shorter

- Direction of rainfall has changed; used to come from the East but now comes from the South and with thunder and cyclones (last 10-20 years)

- Droughts e.g. 1985/86, 1991/2, 2007/8

In Hwedza, 81\% of farmers reported that average temperatures in 2012/2013 had increased compared to 20 years before-hand, with 62\% of farmers in Mbire making the same observation (Fig 8). A higher proportion of farmers in Hwedza district (81\%), than in Mbire district (62\%) claimed that average temperatures had increased.

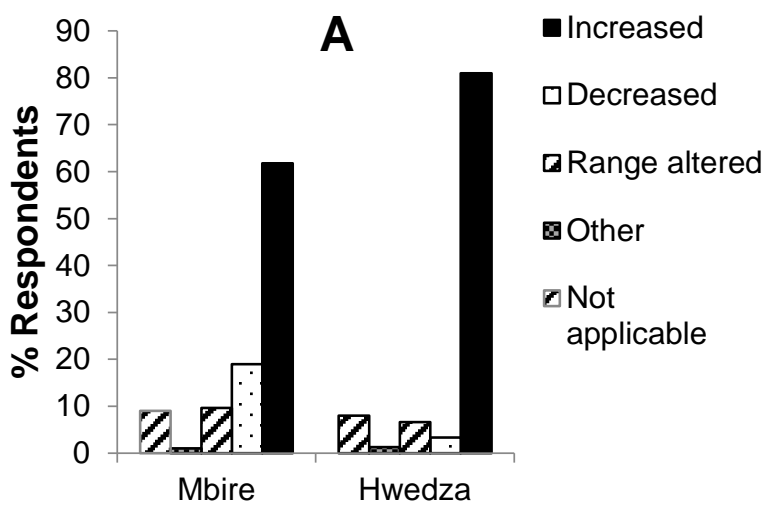

Fig. 1 Farmer perceptions of changes in (A) mean temperature and (B) rainfall in their district between 2012/2013 and 20 years beforehand 
A further $10 \%$ and $7 \%$ of respondents in Mbire and Hwedza respectively observed that temperature range had altered, although they did not specify whether it had decreased or increased. Mean annual rainfall was noted to have decreased by $78 \%$ of farmers in Hwedza and 62\% in Mbire (Fig 8).

\subsection{Postharvest adaptations in response to climate-related challenges}

The mean area under maize production reported by individual households was below 1 ha in both the 2011/2012 and 2012/2013 season, and for sorghum was below 0.52 ha in both districts. Both districts reported over a 12\% decline in the production area for both maize and sorghum between the 2011/2012 to 2012/2013 agricultural seasons (Table 7). In Hwedza, 98\% of respondents stated maize was their main staple crop with just $0.3 \%$ selecting sorghum. While in Mbire, $77.1 \%$ of respondents stated maize was their main staple crop and 18.3\% selected sorghum. Mean purchases of maize for home consumption were considerably higher in Mbire (522.0 kg) than Hwedza (347.5 kg), while for sorghum, purchases were much higher in Hwedza (900.0 kg), than Mbire (373.6 kg).

Table 7 Mean household grain production area, harvested quantity, quantity consumed and sold, current stock and storage duration

\begin{tabular}{|c|c|c|c|c|c|c|c|c|c|}
\hline \multirow{3}{*}{ Parameter } & \multirow{3}{*}{ Period } & \multicolumn{4}{|c|}{ MAIZE } & \multicolumn{4}{|c|}{ SORGHUM } \\
\hline & & \multicolumn{2}{|c|}{ Hwedza } & \multicolumn{2}{|c|}{ Mbire } & \multicolumn{2}{|c|}{ Hwedza } & \multicolumn{2}{|c|}{ Mbire } \\
\hline & & Mean & $N$ & Mean & $N$ & Mean & $N$ & Mean & $N$ \\
\hline \multirow[t]{2}{*}{ Area } & $\begin{array}{l}\text { Production in 2011/2012 } \\
\text { (ha) }\end{array}$ & $0.967 \mathrm{a}$ & 294 & $0.681_{b}$ & 275 & $0.175_{a}$ & 28 & $0.491_{b}$ & 105 \\
\hline & $\begin{array}{l}\text { Production in 2012/2013 } \\
\text { (ha) }\end{array}$ & $0.940_{\mathrm{a}}$ & 295 & $0.717 \mathrm{~b}$ & 275 & $0.165 \mathrm{a}$ & 26 & $0.514_{b}$ & 104 \\
\hline \multirow[t]{2}{*}{ Harvest } & 2011/2012 (kg) & $682.90_{a}$ & 283 & $615.32_{a}$ & 188 & $275.00_{a}$ & 11 & $430.33_{a}$ & 75 \\
\hline & 2012/2013 (kg) & 599.37a & 285 & $443.90_{b}$ & 196 & $234.44_{a}$ & 18 & $375.61_{\mathrm{a}}$ & 66 \\
\hline \multirow[t]{2}{*}{ Sold } & 2011/2012 (kg) & $367.32_{\mathrm{a}}$ & 56 & $555.00_{a}$ & 10 & 5 & 1 & 200 & 2 \\
\hline & 2012/2013 (kg) & $357.21_{\mathrm{a}}$ & 43 & $455.566_{a}$ & 9 & 30 & 2 & 100 & 1 \\
\hline \multirow{2}{*}{$\begin{array}{l}\text { Sales } \\
\text { income }\end{array}$} & 2011/2012 (US\$) & $172_{a}$ & 53 & $158_{\text {a }}$ & 8 & 75 & 1 & 64 & 4 \\
\hline & 2012/2013 (US\$) & $113_{\mathrm{a}}$ & 42 & 168 a & 8 & 16 & 2 & 21 & 1 \\
\hline Purchased & $\begin{array}{l}\text { For home consumption } \\
\text { (kg) }\end{array}$ & $347.49_{a}$ & 197 & $522.04_{b}$ & 203 & 900.01 & 1 & 373.6 & 25 \\
\hline \multirow{3}{*}{$\begin{array}{l}\text { Stocks } \\
\text { Retention } \\
\text { period }\end{array}$} & Current (2013/2014) (kg) & $340.21_{a}$ & 210 & $384.77 a$ & 66 & $130.00_{a}$ & 7 & $220.00_{a}$ & 15 \\
\hline & 2012/2013 (months)* & $4 \mathrm{a}$ & 153 & $0_{\mathrm{b}}$ & 279 & $8 \mathrm{a}$ & 299 & $5 \mathrm{~b}$ & 301 \\
\hline & $\begin{array}{l}10-20 \text { years ago } \\
\text { (months)* }\end{array}$ & $3 a$ & 3 & $3 \mathrm{a}$ & 7 & $13 \mathrm{a}$ & 295 & $11_{b}$ & 301 \\
\hline
\end{tabular}

* Values associated with low responses are for comparison only and may not be a true reflection of possible results 
417

418

There has been a significant decrease in the stored maize retention period in Mbire with respondents indicating few farmers retain their harvested maize grain beyond three months' storage (Table 7).

\subsection{Grain marketing and alternative livelihood strategies}

Average annual household maize grain sales of $367 \mathrm{~kg}$ and $555 \mathrm{~kg}$ were reported in Hwedza and Mbire respectively in the 2011/2012 season, while in the subsequent season (2012/2013) sales declined to an average of $357 \mathrm{~kg}$ and $456 \mathrm{~kg}$ for Hwedza and Mbire respectively (Table 7). Sorghum sales averaged less than $5 \mathrm{~kg}$ and $200 \mathrm{~kg}$ per annum in Hwedza and Mbire respectively in the 2011/2012 season with an increase in the subsequent season to $30 \mathrm{~kg}$ for Hwedza and a decrease to $100 \mathrm{~kg}$ in Mbire (Table 7). In both districts, annual household sales income from maize was more than twice that earned from sorghum. Many of the farmers in both Hwedza (57\%) and Mbire (41\%) preferred to sell their maize grain to well-established marketing agencies; namely the Grain Marketing Board (GMB); with a significant number (30\% in Hwedza and 25\% in Mbire) selling maize grain to neighbours. Stakeholders in Mbire also confirmed that farmers were increasingly abandoning the selling of their maize grain to GMB, opting instead to sell to private traders who paid cash on-the-spot although the prices offered were much lower than those offered by GMB. Food aid dependence was higher in Mbire with all respondents indicating that they often needed food aid, while in Hwedza less than $20 \%$ required food aid.

Farmers were aware of the changes in their seasons and environment, but the lack of postharvest training was highlighted by community key informants and FGDs in both districts. Farmers sought explanations, knowledge, skills and training from their extension staff who they perceive as their major sources of agricultural information.

Table 8 Different postharvest adaptation strategies used by smallholder farmers in response to shifts in rainfall as reported in FGDs and by key informants in Mbire and Hwedza districts, Zimbabwe

\begin{tabular}{ll|l}
\hline \multicolumn{1}{c|}{ Hwedza } & \multicolumn{1}{|c}{ Mbire } \\
\hline - $\begin{array}{l}\text { Choosing varieties that tolerate storage pests } \\
\text { Changing from traditional meal sharing practices } \\
\text { (i.e. many people eating from the same plates) to } \\
\text { individual plates to provide equal meal size } \\
\text { distribution }\end{array}$ & $\begin{array}{l}\text { Increased use of commercial grain } \\
\text { protectants } \\
\text { and wild fruits for future sale or } \\
\text { consumption during periods of lean food } \\
\text { supplies }\end{array}$ \\
\hline
\end{tabular}


The barriers hampering the adoption of coping strategies mentioned by farmers (Table 8), included their knowledge gaps regarding appropriate pesticides and their proper use for managing storage insect pest pressures. In Mbire, challenges to livestock-grain trade identified by stakeholders included: lack of livestock breeds adapted to the higher temperatures, especially bulls to improve livestock production; increased threat to livestock by wild animals; lack of participation by the national custodians of grain trade, the Grain Marketing Board (GMB) to enhance fair livestockgrain trading; and as in Hwedza, lack of knowledge regards effective postharvest technologies.

\subsection{Access to information}

In Hwedza, $87 \%$ of the responding households owned a cellphone, while in Mbire $80 \%$ did, and ownership was even across the sexes in both districts. However, cellphone ownership did not appear to have a significant relationship $\left(\chi^{2}=2.543, \mathrm{p}=0.065\right)$ with how farmers accessed postharvest information, $47 \%$ and $39 \%$ of farmers used cellphones to access postharvest information in Hwedza and Mbire, respectively.

Over $90 \%$ of households surveyed in both districts reported having access to agronomic and postharvest information, with agricultural extension accounting for 43\%, farmer-to-farmer exchanges (22\%) and radio/TV (21\%) (Table 9). General climatic / weather information was accessed by $77 \%$ and $68 \%$ of households, and daily or three-day weather forecasts by just $49 \%$ and $57 \%$ of responding households in Hwedza and Mbire districts respectively. The agronomic information from extension officers was considered reliable by more than $60 \%$ of farmers in both districts. Most responding households, 68\% in Hwedza and 81\% in Mbire, felt specific postharvest handling information was accessible in time for the postharvest activities.

Table 9 Percentage of respondents reporting having access to different types of agro-climatic information in Hwedza and Mbire districts, Zimbabwe

\begin{tabular}{lc|c}
\hline & $\begin{array}{c}\text { Hwedza (\%) } \\
(\mathrm{N}=300)\end{array}$ & $\begin{array}{c}\text { Mbire (\%) } \\
(\mathrm{N}=301)\end{array}$ \\
\hline Agronomic and postharvest & $88.7_{\mathrm{a}}$ & $93.0_{\mathrm{a}}$ \\
Animal production and health & $64 . \mathrm{a}_{\mathrm{a}}$ & $87.0_{\mathrm{b}}$ \\
Agricultural commodity markets and prices & $56.0_{\mathrm{a}}$ & $62 . \mathrm{b}_{\mathrm{b}}$ \\
Climatic/weather in general & $76.7_{\mathrm{a}}$ & $67 . \mathrm{a}_{\mathrm{a}}$ \\
Seasonal forecasts & $65.3_{\mathrm{a}}$ & $67 . \mathrm{a}_{\mathrm{a}}$ \\
Daily/ 3 day weather forecasts & $49.3 \mathrm{a}$ & $57 . \mathrm{a}_{\mathrm{a}}$ \\
Post-harvest handling & $67.7_{\mathrm{a}}$ & $81.4 \mathrm{~b}$ \\
\hline
\end{tabular}




\begin{tabular}{clrrrr|rrrr}
\hline & & \multicolumn{3}{c|}{ Agronomic information (\%) } & \multicolumn{3}{c}{ Postharvest handling (\%) } \\
\cline { 3 - 10 } & & Good & Fair & Poor & N/A & Good & Fair & Poor & N/A \\
\hline Hwedza & Traditional leaders & 29 & 57 & - & 14 & 50 & 50 & - & - \\
$(\mathrm{N}=300)$ & Community leaders & 14 & 72 & 14 & - & - & 80 & 20 & - \\
& Elders & 43 & 43 & 11 & 3 & 37 & 52 & 11 & - \\
& Own observation & 43 & 57 & - & - & 41 & 59 & - & - \\
\hline \multirow{2}{*}{ Mbire } & Traditional leaders & 25 & 71 & 4 & - & 15 & 77 & 8 & - \\
$(\mathrm{N}=301)$ & Community leaders & 12 & 83 & 3 & 2 & 25 & 69 & 6 & - \\
& Elders & 29 & 59 & 9 & 3 & 15 & 74 & 10 & - \\
& Own observation & 11 & 78 & 11 & - & 12 & 83 & 4 & 2 \\
\hline
\end{tabular}

Note: Values in the same row not sharing the same subscript are significantly different at $p<.05$ in the two-sided test of equality for column proportions. Cells with no subscript are not included in the test. Tests assume equal variances.

Table 10 Reliability of indigenous knowledge sources for agronomic and postharvest handling information as perceived by smallholder farmers in Mbire and Hwedza districts, Zimbabwe

The reliability of the information was mainly considered good (Hwedza 55.6\%; Mbire 46.9\%) or fair (Hwedza 32.7\%; Mbire 45.7\%). Stakeholders interviews confirmed that weather information was received from a variety of sources in both Hwedza and Mbire districts, including media sources such as radio, television and newspapers, Agricultural, Technical and Extension Services (AGRITEX), Non-Governmental Organisations (NGOs), Soil Fertility Consortium of Southern Africa (SOFECSA) in the case of Hwedza, and the Meteorological Department. Community-based sources included indigenous knowledge systems, churches, community discussions and school children. Indigenous weather indicators included observing wind behaviour; growth, flowering and fruiting patterns of trees; and insect behavioural patterns.

Indigenous knowledge sources were mainly perceived to be a fair or good source of agronomic and postharvest handling information in both districts (Table 10). Elders and own observations were highly regarded postharvest handling knowledge sources in Hwedza (37\% and 41\% good, respectively), and traditional leaders (50\% good) and community leaders in Mbire (25\% good). 


\subsection{Potential hazards of poor grain storage management practices}

495

496

497

498

499

500

501

502

503

504

505

506

507

508

509

510

511

512

513

514

515

516

517

518

519

520

521

522

523

524

Storage of grain has largely shifted from traditional outdoor stand-alone granaries to indoor storage in polypropylene bags kept inside the family's living-quarters. This change indicates an increase in the cautiousness and concerns of smallholders regarding their grain storage systems and their shortand long-term food budgeting strategies. This change also results in increased secrecy regarding postharvest management which likely hinders sharing of postharvest management information within communities as compared to the past when granaries were external and seen as social status symbols that households were proud to display. Focus groups and key informants noted that construction of traditional granaries, a task previously undertaken by men for income generation, no longer commonly occurred as most people were, for security reasons, now storing their grain in polypropylene bags placed the family's living quarters. Respondents associated this change with increased cases of grain theft due to high rates of unemployment and increased economic hardship (Saungweme 2013) exacerbated by persistent food shortages due to climate-induced mid-season droughts which often resulted in crop failure. Traditional store management practices including the seasonal plastering of cow-dung slurry on well-swept earth walls and floors of granaries do not apply to living rooms. However, storage of fumigated or synthetic pesticide-treated grain in polypropylene bags stacked in the family rooms is of concern, given the likelihood of the inhabitants then inhaling toxic fumigants and synthetic pesticides (passive exposure) which can be detrimental to human health; particularly for children (Liu and Schelar 2012). Increased pesticide use without adherence to regulated dosages (Damalas and Eleftherohorinos 2011; Mvumi et al. 1995; Rozman et al. 2007) may also contribute to increased pest resistance and ultimately reduce the effectiveness of the protectant. Other factors that could exacerbate postharvest losses is the use of high-yielding but more susceptible hybrid varieties (Golob, 1984; Giga \& Mazarura, 1991; Kossou et al., 1993; Boxall, 2001) and poor storage management practices.

\subsection{Effects of climate on storage pest-related challenges}

Farmers may not fully understand the extent, nature and interconnectivity of their postharvest challenges but storage pest attack was reported as a major underlying factor. Many respondents perceived the increase in temperatures as having a direct impact on the increase in pest-related problems as has been reported in similar studies (Moyo et al. 2012; Nyanga et al. 2011). This was corroborated by farmer perceptions of increased seasonality of pests which can be linked to climatic changes that affect insect bionomics (Neven 2000; Willmer et al. 2005). While the current study did not ask respondents about the impact on specific postharvest pests, there is need to investigate 
how increasing temperatures affect the life cycles of economically important postharvest insect pests (Sharma and Prabhakar 2014) including P. truncatus, Rhyzopertha dominica (F.), Sitophilus spp., Sitotroga cerealella (Olivier), and bruchids. The farmers reported that postharvest pest attack begins in the field during field drying of grain crops and then continues and increases once the grain is in storage. Prostephanus truncatus is a highly destructive stored maize grain insect pest, which is now endemic in most parts of SSA (Borgemeister et al., 1998; Nyagwaya et al., 2010; Muatinte et al., 2014; Muatinte et al., 2019) and may continue to spread to other geographical areas with similar host crops, host vegetation and/or environmental conditions aided by global warming.

\subsection{Postharvest management and the use of grain}

The effectiveness of the currently available storage pesticides was also questioned, with over 25\% of farmers in both Hwedza and Mbire districts citing an increase in insect pest population and pesticide resistance as the most important reasons why they perceived the pesticides were no longer effective. A high incidence of recycling the seed of previously harvested hybrid maize varieties occurs in Hwedza, likely due to the high cost of purchasing hybrid seed. Retained maize seed may be a key source of carry-over pest infestation owing to its longer retention period. In Hwedza, farmers use the holes in maize kernels as a sign of insect damage. However, this is harder to do with the much smaller sorghum grains, which are the main stored grain in Mbire. More precise methods for sampling and detecting insect damage could help farmers determine pest problems earlier and inform their corrective measures. It is recommended that an effective protectant method be used at the start of storage on all grain that is intended to be stored for longer than three months. Prostephanus truncatus and other primary storage insect pests are known to favour hybrid varieties of maize for field infestation due to the inadequate husk cover which exposes grains on the cob (Boxall 2002; Kasambala et al. 2012). Hence, the combined effects of retained seed-use, sale and exchange of infested home-retained grain, and use of hybrids creates a high pest infestation risk situation. Only commercial traders such as GMB and milling companies fumigate infested grain upon delivery to prevent cross-infestation and further damage.

Other parts of this study initiated research work comparing the efficacy of storage technologies for maize (S. Mlambo et al. 2018; Shaw Mlambo et al. 2017) and sorghum (Mubayiwa et al., 2018; Mubayiwa, 2019) under different agro-climatic conditions in Hwedza and Mbire districts of Zimbabwe (S. Mlambo et al. 2018; Shaw Mlambo et al. 2017) and Masvingo province (Chigoverah and Mvumi 2016). In these storage trials, hermetic devices and new synthetic chemical grain protectant products successfully protected stored grain across agro-ecological zones. The current study found botanical pesticide use had decreased, although it may provide a viable alternative to 
562

563

564

565

566

567

568

569

570

571

572

573

574

575

576

577

578

579

580

581

582

583

584

585

586

587

588

589

590

591

592

593

594

595

commercially-available grain protectants (Stevenson et al. 2014) especially if use and propagation can be optimised.

Stakeholder interviews suggested there had been a shift to short-term food budgeting strategies due to lower production levels, given average yields are as low as $0.5 \mathrm{t} \mathrm{ha}^{-1}$. Respondents in Mbire have a high dependence on food aid, with stakeholders confirming that the climatic challenges make it hard for households to produce enough food. Although sorghum has a higher cropping success rate in Mbire, it is less preferred as a staple food and mainly considered a secondary food source. Food aid can be a potential source of pest spread, as noted from the origin and spread of $P$. truncatus into Africa (Dunstan and Magazini 1980; Harnish and Krall 1984). Dependency on and potential anticipation of food aid can affect the quality of survey data - where participants hope their responses may result in relief food - despite clear explanations that the data being collected were for was research purposes only.

Numerous drivers are provoking change in crop storage systems including increased theft, high and variable grain prices, devastating effects of pest attack, limited postharvest extension knowledge or sharing, climate change and increasing climate variability. Adjusting cropping systems could improve coping and adaptation strategies, with the drier conditions in Mbire being more suitable for more livestock-oriented production; allowing for possible grain-livestock exchange with relatively wetter areas such as Hwedza where crop production is more suitable. Some of the responses in the study suggest that farmers and extension agents are not used to being asked about the postharvest and climate change elements of their farming systems, with most studies and training still focusing on agronomy, field pest management and methods for increasing crop yield.

\subsection{Information management}

Although cellphone ownership was high in both districts (> 80\%), over 39\% of cellphone owners still depended on physical meetings with extension officers for their agronomic and postharvest information, with the gender of the $\mathrm{HHH}$ having little influence.. Key informants reported that climate information was obtained from a variety of sources but was too limited in scope and lacked significant inputs from research. Extension agents have a critical role to play in sourcing and delivering the right information to farmers but they are generally not well-trained in postharvest issues (Mvumi and Stathers 2014). Farmers rely on their own experience for their decision-making. Sustained and systematic training of both extension staff and farmers could help reinforce and improve habitual postharvest practices and reduce postharvest losses. 
597 Women were more involved than men in the postharvest activities suggesting attention needs to 598 focus on helping them to adapt to climate change using new farming methods (Nhemachena and Hassan 2007), while a focus on children as farmers of the future could also be beneficial (Katanha and Chigunwe 2014). Almost 50\% of the farmers ranked indigenous postharvest information as being fair to good in terms of reliability. Lack of documentation related to indigenous knowledge and its dependency on oral and inter-generational knowledge transfer, make it unreliable as a method for forecasting weather (Jiri et al., 2015), because it does not integrate newer scientific methodologies (Nyong et al. 2007; Patt and Gwata 2002) such as tools to aid adoption of new grain storage technologies.

606

\subsection{Marketing, livelihood strategies and other practices}

In Mbire, where dirt roads dominate, the nearest GMB depot was 50+ $\mathrm{km}$ away through either selling their grain to traders/dealers or bartering grain and livestock for goods and/or services. Contrastingly, Hwedza has a good road network with a tarmac highway and is closer to big cities such as Marondera and Harare which allow for more off-farm activities such as, carpentry, flea markets and vending. . The major coping strategies for the majority of farmers in Mbire were centered on livestock barter-trade with grain or other household needs. Lower production levels of both maize and sorghum due to reduced and more unpredictable rainfall and increased dry spells and droughts (Nangombe 2014) also lead to lower quantities being sold.

River bank cultivation is rife in Mbire, with maize and other crops grown out-of-season using the residual moisture in riverside or riverbed fields as alsoreported by Bola et al. (2013). Sorghum is an important traditional grain crop grown in Mbire, although only 18\% of farmers were growing the crop which is largely viewed as secondary to maize due to the general shift to higher-yielding maize hybrids, plus the high labour requirements and low market value of traditional grains. Maize is also the preferred food aid crop distributed by NGOs especially in Mbire where food aid is regularly required.

Cash crops (e.g. cotton) and livestock are major sources of income in Mbire whereas Hwedza is more climatically favourable for maize production, explaining why more maize stock was reported in in the latter. Experiential visual assessment was the most commonly used grain moisture content testing method though it is not standardized and can be unreliable for optimizing delivery to GMB 
or moisture has nutritional implications since some insect pests target specific nutrients in the kernels (Behmer 2005; T. E. Stathers et al. 2020). High grain moisture content which may result from insufficient drying, insect infestation or re-wetting may facilitate fungal growth and potential mycotoxin and aflatoxin production which are harmful to humans and livestock (Moses et al. 2015).

\subsection{Implications for postharvest policy}

Developing policies and strategies to address postharvest management and food security is key in tackling threats posed by a changing climate and associated changes in postharvest management practices coupled with greater postharvest pest threats. For instance, in Zimbabwe policy requiring all deliveries to be made to GMB (Kapuya et al. 2010) combined with challenges in GMB meeting payment deadlines has resulted in farmers side-marketing the grain. Anecdotal evidence shows there is substantial grain movement in small batches between different households and to different locations around Zimbabwe (including urban areas). This could contribute to the spread of grain storage pests such as $P$. truncatus which affects the quantity and nutritional value of stored food (Ekpa et al. 2018; T. E. Stathers et al. 2020), requiring further investigation with respect to different grain types, management practices and climate variables. In addressing policy issues, the African Union has put in place the Comprehensive Africa Agriculture Development Programme policy framework of 2012 but there is inadequate articulation of the specific postharvest aspects although it targets the reduction of postharvest losses by 50\% by 2025 (AUC 2014). Organisations such as the Food, Agriculture and Natural Resources Policy Analysis Network are building policy dialogue around postharvest issues with the aim of getting more policies in sub-Saharan Africa directed towards postharvest management. Postharvest research data can help build the evidence-base needed for dialoguing with policy-makers and directing and driving supportive policy change.

\section{Conclusion}

The study explored existing postharvest management practices and perceptions of smallholder farmers and their service-providers in the context of climate change. Many of the current pest management methods, such as synthetic chemical grain protectants and botanical products require further investigation as indications suggest they are failing to control new pests, or are rendered less effective by the development of pest tolerance or changes in climatic conditions. Farmers' coping strategies are currently devoid of research inputs to help inform their decision-making. The overreliance on, and increasing use of synthetic pesticides is concerning given the negative health implications of pesticide mishandling, including incorrect dosages, wrong application methods, use of pesticides not registered for application on food and the storage of grain inside houses. While 
666

667

668

669

670

671

672

673

674

675

676

677

678

679

680

681

682

683

684

685

686

687

688

689

anecdotal evidence suggests a growing $P$. truncatus problem, more work is required to determine the extent of spread and damage by this pest in the focal areas and beyond.

Given the different but concurrent stressors, including climate and its long-term effect on pest populations, the lack of postharvest knowledge amongst farmers and their service-providers should be flagged as major household food security issues. There is scope for much greater knowledge sharing through participatory community-based interaction in postharvest research, and technology development and promotion. Differences in socio-economic circumstances, access to physical infrastructure, climate and agroecology and their potential impacts on postharvest management practices emphasize the importance of taking the heterogeneity in farmer circumstances into consideration when developing solutions. The study creates a basis from which to develop future research and capacity strengthening activities on grain postharvest management in smallholder agriculture. A concerted multi-dimensional effort including progressive policies and enabling environment, is required to bring indigenous knowledge systems, extension and research personnel together to achieve sustainable improved grain postharvest management which will help farmers strengthen their resilience and capacity to adapt to the impacts of climate change and variability.

\section{Acknowledgements}

The authors would like to thank the European Union (EU) for funding the research project "Supporting smallholder farmers in southern Africa to better manage climate-related risks to crop production and postharvest handling" through the Food and Agriculture Organization (FAO) (Grant No. DCI-FOOD/2012/304-807). Our gratitude is also extended to the respondent farmers and national extension services for their cooperation, contributions and active participation. 


\section{References}

APHLIS. (2019). Zimbabwe Cereal Postharvest Losses. Zimbabwe Cereal Postharvest Losses. www.aphlis.net. Accessed 23 February 2019

Arkkelin, D. (2014). Using SPSS to Understand Research and Data Analysis. Psychology Curricular Materials 2014, 194. https://doi.org/doi: http://scholar.valpo.edu/psych_oer/1

AUC. (2014). Malabo Declaration on accelerated agricultural growth and transformation for shared prosperity and improved livelihoods. Malabo, Equatorial Guinea. June 26-27, 2014. AUC. https://au.int/sites/default/files/documents/31006-doc-malabo_declaration_2014_11_26-.pdf. Accessed 23 August 2020

Behmer, S. T. (2005). Nutrition in insects. In Encyclopedia of Entomology (pp. 1577-1582). Dordrecht: Springer Netherlands. https://doi.org/10.1007/0-306-48380-7_2923

Bola, G., Mabiza, C., Goldin, J., Kujinga, K., Nhapi, I., Makurira, H., \& Mashauri, D. (2013). Coping with droughts and floods: A Case study of Kanyemba, Mbire District, Zimbabwe. Physics and Chemistry of the Earth, Parts A/B/C, 67-69, 180-186. https://doi.org/10.1016/j.pce.2013.09.019

Borgemeister, C., Adda, C., Sétamou, M., Hell, K., Djomamou, B., Markham, R. H., \& Cardwell, K. F. (1998). Timing of harvest in maize: Effects on post harvest losses due to insects and fungi in central Benin, with particular reference to Prostephanus truncatus (Horn) (Coleoptera: Bostrichidae). Agriculture, Ecosystems and Environment, 69(3), 233-242. https://doi.org/10.1016/S0167-8809(98)00109-1

Boxall, R. A. (2002). Damage and loss caused by the Larger Grain Borer ,Prostephanus truncatus. Integrated Pest Management Reviews, 7(2), 105-121. https://doi.org/10.1023/A:1026397115946

Brown, D., Chanakira, R. R., Chatiza, K., Dhliwayo, M., Dodman, D., Masiiwa, M., et al. (2012). Climate change impacts, vulnerability and adaptation in Zimbabwe. International Institute for Environment and Development. https://www.jstor.org/stable/resrep01235. Accessed 20 February 2019

Chigoverah, A., \& Mvumi, B. (2016). Efficacy of metal silos and hermetic bags against stored-maize insect pests under simulated smallholder farmer conditions. Journal of Stored Products Research, 69, 179-189. https://doi.org/10.1016/j.jspr.2016.08.004

Damalas, C., \& Eleftherohorinos, I. (2011). Pesticide exposure, safety issues, and risk assessment Indicators. International Journal of Environmental Research and Public Health, 8(5), 1402-1419. https://doi.org/DOI: 10.3390/ijerph8051402

Dube, F., Nhapi, I., Murwira, A., Gumindoga, W., Goldin, J., \& Mashauri, D. A. (2014). Potential of weight of evidence modelling for gully erosion hazard assessment in Mbire District - Zimbabwe. Physics and Chemistry of the Earth, Parts A/B/C, 67-69, 145-152. https://doi.org/10.1016/j.pce.2014.02.002

Dunstan, W. R., \& Magazini, I. (1980). Outbreaks and new records. Tanzania. The larger grain borer on stored products. FAO Plant Protection Bulletin, 29, 80-81.

Ekpa, O., Palacios-Rojas, N., Kruseman, G., Fogliano, V., \& Linnemann, A. R. (2018). Sub-Saharan African maize-based foods: Technological perspectives to increase the food and nutrition security 
impacts of maize breeding programmes. Global Food Security, 17, 48-56. https://doi.org/10.1016/j.gfs.2018.03.007

730

731

732

733

Gadzirayi, C. T., Mutandwa, E., \& Mupangwa, J. F. (2007). Veld condition trend of grazing areas: Why poor livestock production in the tropics? Rangelands, 29(1), 17-21. https://doi.org/10.2111/1551501X(2007)29[17:VCTOGA]2.0.CO;2

Harnish, R., \& Krall, S. (1984). Further distribution of the larger grain borer in Africa. FAO Plant Protection Bulletin, 32(3), 113-14.

IPCC. (2014). Climate Change 2014: Synthesis Report. Contribution of Working Groups I, II and III to the Fifth Assessment Report of the Intergovernmental Panel on Climate Change (pp. 3-87). Intergovernmental Panel on Climate Change. https://www.ipcc.ch/site/assets/uploads/2018/05/SYR_AR5_FINAL_full_wcover.pdf

Kapuya, T., Saruchera, D., Jongwe, A., Mucheri, T., Mujeyi, K., Traub, L., \& Meyer, F. (2010). The Grain Industry Value Chain in Zimbabwe (Technical Report). DOI: 10.13140/2.1.4791.6325

Karuppaiah, V., \& Sujayanad, G. K. (2012). Impact of climate change on population dynamics of insect pests. World Journal of Agricultural Sciences, 8, 240-246.

Kasambala, T., Chinwada, P., \& Mvumi, B. (2012). Evaluation of the susceptibility of maize hybrid Varieties to Prostephanus truncatus (Bostrichidae: Coleoptera) in Malawi. Presented at the National Commission for Science and Technology Research Dissemination, Lilongwe, Malawi. https://www.researchgate.net/publication/255696406_Evaluation_of_the_Susceptibility_of_Maize _Hybrid_Varieties_to_Prostephanus_truncatus_Bostrichidae_Coleoptera_in_Malawi

Katanha, A., \& Chigunwe, G. (2014). Climate change adaptation challenges in semi-arid region of Dande Valley in Zimbabwe. International Journal of Science and Research, 3(7), 633-640.

Kpolovie, P. (2017). Statistical Analysis with SPSS for Research (First.). UK: European Centre for Research Training and Development. https://www.researchgate.net/publication/319981226_statistical_analysis_with_SPSS_for_research

Liu, J., \& Schelar, E. (2012). Pesticide exposure and child neurodevelopment. Workplace Health \& Safety, 60(5), 235-242. https://doi.org/10.1177/216507991206000507

Macdonald, S. (2003). Winter Cricket: The spirit of Wedza; a collection of biographies, articles, memories and recollections. Harare, Zimbabwe: Conlon Printers.

Mapfumo, P., Chikowo, R., \& Mtambanengwe, F. (2010). Lack of resilience in African smallholder farming : exploring measures to enhance the adaptive capacity of local communities to pressure climate change : final technical report - Zimbabwe (October 2010). https://idl-bncidrc.dspacedirect.org/handle/10625/46032. Accessed 21 February 2019

Ministry of Environment and Natural Resources Management. (2013). Zimbabwe National Climate Change Response Strategy. International Journal of Scientific \& Technology, 2(8). http://www.cytel.com/hubfs/0-library-0/pdfs/SP07.pdf. Accessed 20 June 2017

Mlambo, S., Mvumi, B. M., Stathers, T., Mubayiwa, M., \& Nyabako, T. (2018). Field efficacy and persistence of synthetic pesticidal dusts on stored maize grain under contrasting agro-climatic 
conditions. Journal of Stored Products Research, 76, 129-139. https://doi.org/10.1016/j.jspr.2018.01.009

768

769

770

771

Mlambo, Shaw, Mvumi, B. M., Stathers, T., Mubayiwa, M., \& Nyabako, T. (2017). Field efficacy of hermetic and other maize grain storage options under smallholder farmer management. Crop Protection, 98, 198-210. https://doi.org/10.1016/j.cropro.2017.04.001

Moses, J. A., Jayas, D. S., \& Alagusundaram, K. (2015). Climate change and its implications on stored food grains. Agricultural Research, 4(1), 21-30. https://doi.org/10.1007/s40003-015-0152-z

Moyo, M., Mvumi, B. M., Kunzekweguta, M., Mazvimavi, K., \& Craufurd, P. (2012). Farmer perceptions on climate change and variability in semi-arid Zimbabwe in relation to climatology evidence. African Crop Science Journal, 20, 317-335.

Muatinte, B., Boukouvala, M., García-Lara, S., \& López-Castillo, L. M. (2019). The threat of the larger grain borer, Prostephanus truncatus (Coleoptera: Bostrichidae) and practical control options for the pest. CAB Reviews Perspectives in Agriculture Veterinary Science Nutrition and Natural Resources, 14, 1-25.

Muatinte, B. L., Van Den Berg, J., \& Santos, L. A. (2014). Prostephanus truncatus in Africa : A Review of biological trends and perspectives on future pest management Strategies. African Crop Science Journal, 22(3), 237-256.

Mubaya, C. P., Njuki, J., Mutsvangwa, E. P., Mugabe, F. T., \& Nanja, D. (2012). Climate variability and change or multiple stressors? Farmer perceptions regarding threats to livelihoods in Zimbabwe and Zambia. Journal of Environmental Management, 102, 9-17. https://doi.org/10.1016/j.jenvman.2012.02.005

Mubayiwa, M., Mvumi, B. M., Stathers, T. E., Mlambo, S., \& Nyabako, T. (2018). Blanket application rates for synthetic grain protectants across agro-climatic zones: Do they work? Evidence from field efficacy trials using sorghum grain. Crop Protection, 109, 51-61. https://doi.org/10.1016/j.cropro.2018.01.016

Mugandani, R., Wuta, M., Makarau, A., \& Chipindu, B. (2012). Re-classification of agro-ecological regions of Zimbabwe in conformity with climate variability and change. African Crop Science Journal, 20(2), 361-369-369.

Mvumi, B. M., Giga, D. P., \& Chiuswa, D. V. (1995). The maize ( Zea mays L.) post-production practices of smallholder farmers in Zimbabwe: findings from surveys. Journal of Applied Science in Southern Africa, 1(2), 115-130.

Mvumi, B. M., \& Stathers, T. E. (2014). Food security challenges in Sub-Saharan Africa: The potential contribution of postharvest skills, science and technology in closing the gap. In Proceedings of the 11th International Working Conference on Stored-Product Protection (pp. 33-43). Presented at the 11th International Working Conference on Stored-Product Protection, Chiang Mai, Thailand. https://doi.org/10.14455/DOA.res.2014.7

Nang’ayo, F. L. O., Hill, M. G., \& Wright, D. J. (2002). Potential hosts of Prostephanus truncatus (Coleoptera: Bostrichidae) among native and agroforestry trees in Kenya. Bulletin of Entomological Research, 92(6), 499-506. https://doi.org/10.1079/BER2002202 
Nangombe, S. S. (2014). Drought conditions and management strategies in Zimbabwe. Meteorological Services Department, Harare, Zimbabwe. http://www.droughtmanagement.info/literature/UNWDPC_NDMP_Country_Report_Zimbabwe_2014.pdf. Accessed 29 December 2017

Neven, L. G. (2000). Physiological responses of insects to heat. Postharvest Biology and Technology, 21(1), 103-111. https://doi.org/10.1016/S0925-5214(00)00169-1

Nhemachena, C., \& Hassan, R. (2007). Micro-Level analysis of farmers' adaptation to climate change in southern Africa (No. 714) (p. 30). Washington, D.C.: International Food Policy Research Institute (IFPRI) Centre for Environmental Economics and Policy in Africa (CEEPA). http://www.ifpri.org/publication/micro-level-analysis-farmers-adaptation-climate-change-southernafrica. Accessed 21 February 2019

Nyabako, T., \& Manzungu, E. (2012). An assessment of the adaptability to climate change of commercially available maize varieties in Zimbabwe. Environment and Natural Resources Research, 2(1), 32. https://doi.org/10.5539/enrr.v2n1p32

Nyagwaya, L. D. M., Mvumi, B. M., \& Saunyama, I. G. M. (2010). Occurrence and distribution of Prostephanus truncatus (Horn) (Coleoptera: Bostrichidae) in Zimbabwe. International Journal of Tropical Insect Science, 30(4), 221-231. https://doi.org/10.1017/S1742758410000342

Nyamapfene, K. W. (1985). Distribution and management of some problem soils of Zimbabwe. FAO World Resource Bulletin No 58.

Nyanga, P., Johnsen, F., Aune, J., \& Kalinda, T. (2011). Smallholder farmers’ perceptions of climate change and conservation agriculture: Evidence from Zambia. Journal of Sustainable Development, 4(4), p73. https://doi.org/10.5539/jsd.v4n4p73

Nyong, A., Adesina, F., \& Osman Elasha, B. (2007). The value of indigenous knowledge in climate change mitigation and adaptation strategies in the African Sahel. Mitigation and Adaptation Strategies for Global Change, 12(5), 787-797. https://doi.org/10.1007/s11027-007-9099-0

Patt, A., \& Gwata, C. (2002). Effective seasonal climate forecast applications: examining constraints for subsistence farmers in Zimbabwe. Global Environmental Change, 12(3), 185-195. https://doi.org/10.1016/S0959-3780(02)00013-4

Rembold, F., Hodges, R., Bernard, M., Knipschild, H., \& Léo, O. (2011). The African Postharvest Losses Information System (APHLIS) (EUR - Scientific and Technical Research Reports). Luxembourg: Publications Office of the European Union. http://publications.jrc.ec.europa.eu/repository/bitstream/JRC62618/lbna24712enc.pdf

Rozman, V., Kalinovic, I., \& Korunic, Z. (2007). Toxicity of naturally occurring compounds of Lamiaceae and Lauraceae to three stored-product insects. Journal of Stored Products Research, 43(4), 349355. https://doi.org/10.1016/j.jspr.2006.09.001

Rurinda, J., van Wijk, M. T., Mapfumo, P., Descheemaeker, K., Supit, I., \& Giller, K. E. (2015). Climate change and maize yield in southern Africa: what can farm management do? Global Change Biology, 21(12), 4588-4601. https://doi.org/10.1111/gcb.13061

Saungweme, T. (2013). Trade dynamics in Zimbabwe: 1980-2012. International Journal of Economics and Research, 4, 29-38. 
Sharma, H. C. (2014). Climate Change Effects on Insects: Implications for Crop Protection and Food Security. Journal of Crop Improvement, 28(2), 229-259. https://doi.org/10.1080/15427528.2014.881205

Sharma, H. C., \& Prabhakar, C. S. (2014). Chapter 2 - Impact of climate change on pest management and food security. Integrated Pest Management, 23-36. http://dx.doi.org/10.1016/B978-0-12-3985293.00003-8

Stathers, T. E., Arnold, S. E. J., Rumney, C. J., \& Hopson, C. (2020). Measuring the nutritional cost of insect infestation of stored maize and cowpea. Food Security, 12(2), 285-308. https://doi.org/10.1007/s12571-019-00997-w

Stathers, T., Lamboll, R., \& Mvumi, B. M. (2013). Postharvest agriculture in changing climates: its importance to African smallholder farmers. Food Security, 5(3), 361-392. https://doi.org/10.1007/s12571-013-0262-z

Stevenson, P. C., Arnold, S. E. J., \& Belmain, S. R. (2014). Pesticidal plants for stored product pests on small-holder farms in Africa. In Pesticidal Plants for Stored Product Pests on Small-holder Farms in Africa (pp. 149-172). Springer India. https://www.academia.edu/9467141/Pesticidal_Plants_for_Stored_Product_Pests_on_Smallholder_Farms_in_Africa. Accessed 21 February 2019

Tefera, T. (2012). Postharvest Losses in African maize in the face of increasing food shortage. Food Security, 4, 267-277.

Thornton, P. K., Ericksen, P. J., Herrero, M., \& Challinor, A. J. (2014). Climate variability and vulnerability to climate change: a review. Global Change Biology, 20(11), 3313-3328. https://doi.org/10.1111/gcb.12581

Vincent, V., Thomas, R. G., \& Staples, R. R. (1960). An agricultural survey of Southern Rhodesia. Part 1. Agro-ecological survey. Salisbury (S. Rhodesia): Government Printers. https://www.cabdirect.org/cabdirect/abstract/19621701163. Accessed 21 February 2019

Willmer, P., Stone, G., \& Johnston, I. (2005). Environmental Physiology of Animals. Oxford UK: Blackwell Publishing.

Wuta, M., \& Nyamugafata, P. (2012). Management of cattle and goat manure in Wedza smallholder farming area, Zimbabwe. African Journal of Agricultural Research, 7(26), 3853-3859. https://doi.org/10.5897/ AJAR12.038 